\title{
Migration in the Hindu Kush Himalaya: Drivers, Consequences, and Governance
}

\section{Coordinating Lead Authors}

Tasneem Siddiqui, University of Dhaka, Dhaka, Bangladesh, e-mail: tsiddiqui59@gmail.com Ram B. Bhagat, International Institute of Population Sciences, Mumbai, India, e-mail: rbbhagat@iips.net Soumyadeep Banerjee, International Centre for Integrated Mountain Development, Kathmandu, Nepal, e-mail: soumyadeep.banerjee@icimod.org (corresponding author)

\section{Lead Authors}

Chengfang Liu, China Center for Agricultural Policy, School of Advanced Agricultural Sciences, Peking University, Beijing, China, e-mail: cfliu.ccap@pku.edu.cn; liucf@pku.edu.cn

Bandita Sijapati, Centre for the Study of Labour and Mobility, Social Science Baha, Kathmandu, Nepal, e-mail: bsijapati@ceslam.org

Rashid Memon, Lahore University of Management Sciences, Lahore, Pakistan,

e-mail: rashid.memon@lums.edu.pk

Pema Thinley, Ministry of Agriculture and Forests, Thimphu, Bhutan, e-mail: pemathinley@moaf.gov.bt Michiko Ito, International Organization for Migration, Yangon, Myanmar, e-mail: mito@iom.int Orzala Nemat, Afghanistan Research and Evaluation Unit, Kabul, Afghanistan,

e-mail: orzala.an@gmail.com

Ghulam Muhammad Arif, Independent expert, Islamabad, Pakistan, e-mail: gmarif@pide.org.pk

\section{Review Editor}

Richard Black, College of Social Sciences, University of Birmingham, Birmingham, United Kingdom, e-mail: r.black@bham.ac.uk

\section{Corresponding Author}

Soumyadeep Banerjee, International Centre for Integrated Mountain Development, Kathmandu, Nepal, e-mail: soumyadeep.banerjee@icimod.org 


\section{Contents}

Chapter Overview. 518

15.1 Labour Migration in the HKH: A Challenge and Opportunity for Inclusive Growth 521

15.2 Diverse Trends, Consistent Importance of Migration ........................................................... 522

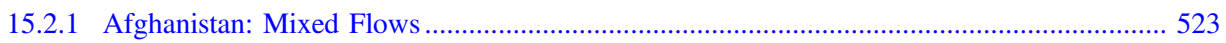

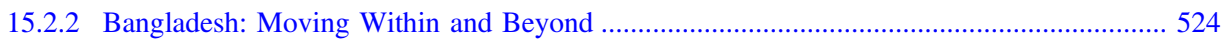

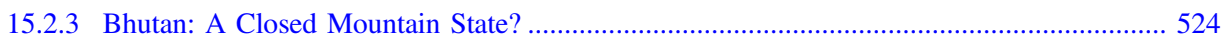

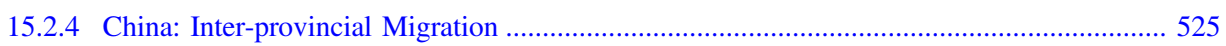

15.2.5 India: Long-Distance Internal Migration ....................................................................... 525

15.2.6 Myanmar: Through the 'Open Doors' ............................................................................ 526

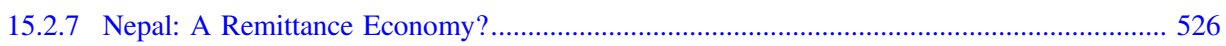

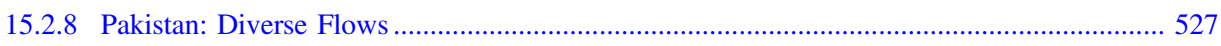

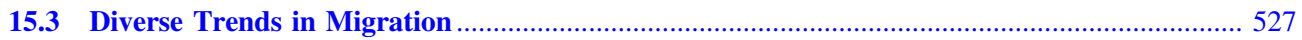

15.3.1 In Search of a Better Life ..................................................................................... 527

15.3.2 Better Educated, Better Connected ……..................................................................... 528

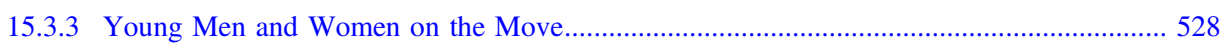

15.3.4 States Policies Shape Migration.................................................................................... 529

15.3.5 Migration: A Strategy for Climate Change Adaptation ..................................................... 530

15.4 Consequences of Labour Migration for Mountain Communities ............................................. 530

15.4.1 Migration Reduces Mountain Poverty and Creates New Livelihood Opportunities ............ 530

15.4.2 Increased School Enrolment, Better Outcomes for Children ............................................ 532

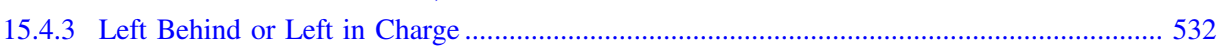

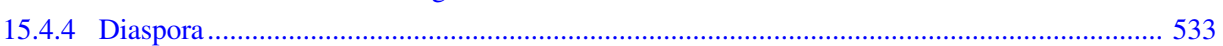

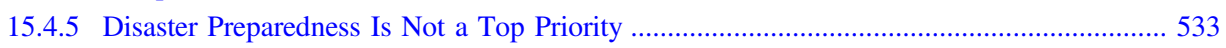

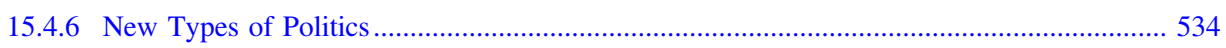

15.5 The Governance of Labour Migration in the HKH Region..................................................... 534

15.5.1 National Policies, Laws and Acts ................................................................................ 534

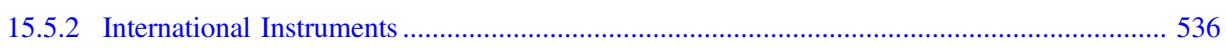

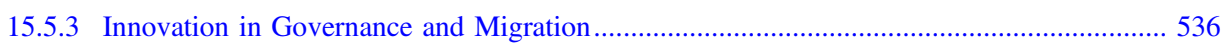

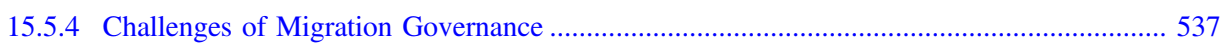

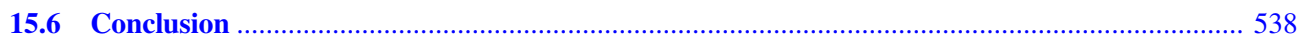

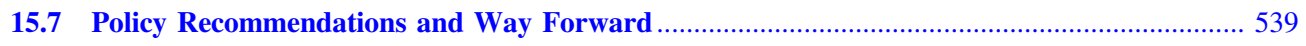

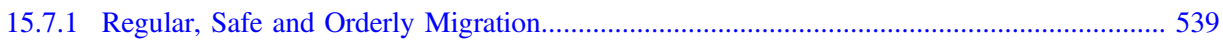

15.7.2 Protection of Migrants' Right and Social Security........................................................... 539

15.7.3 Mainstreaming Migration into Development ..................................................................... 540

15.7.4 Climate Change, Migrants and Urban Cities..................................................................... 540

15.7.5 Collection and Compilation of Migration Data ................................................................. 540

References 540

\section{Chapter Overview}

\section{Key Findings}

1. Migration drives a broad range of economic, social and political changes throughout the $\mathrm{HKH}$, while migration itself is determined by multiple factors. The decision to migrate is influenced by demographic, economic, environmental (including climate change), political and social drivers, as well as by individual and household characteristics, and intervening obstacles and facilitators. In most situations in the HKH region, economic drivers will continue to be the 
most influential among the drivers. The aspirations of youthful populations, concentration of higher education opportunities in urban centres, ever widening transportation infrastructure and continuous improvement in digital communication will bolster the influence of the economic driver.

2. Labour migration contributes significantly to poverty reduction in the HKH region, although this depends on who is able to move, and under what conditions. The effects of migration in sending areas in the HKH region depend on the characteristics of sending household, financial institutions, markets, migration type, public amenities, social networks and social structures. Migration can be seen as a way to promote resilience to climate change, but investment in agriculture or climate adaptation is rarely the first priority of migrant households in mountainous area. Generally, remittances are invested in consumer goods, education, food, health care, and housing.

3. Issues associated with internal migration remain peripheral to the policy discourse of most HKH countries, even though more than three times as many people migrate internally compared to international migration. Moreover, policymakers and planners tend to perceive rural to urban migration as a challenge to urban and rural development. There is a need to mainstream migration in development policies and programmes.

\section{Policy Messages}

1. HKH countries focusing on development will be more successful if policy makers approach migration not as a challenge, but instead seek ways to mainstream it into adaptation, development and risk reduction processes. Such mainstreaming can occur within national policy processes and sub-national programmes associated with the Sustainable Development Goals, the Sendai Framework for Disaster Risk Reduction, and the United Nations Framework Convention on Climate Change. Governments could create enabling conditions that help people to choose whether they migrate to another place or stay where they are, rather than explicitly or implicitly attempting to prevent migration. For this, policy makers, researchers as well as grass roots NGOs in the HKH countries urgently need quality data on seasonal migration, remittances, and reintegration of returnee migrants. To understand better the effects of migration in mountain areas, the census and national sample surveys need to provide mountain-specific data.

2. Social protections - such as the right to access public amenities and services-should be made portable across administrative boundaries. To ensure portability of rights and entitlements, special efforts may be needed in countries with a federal model of governance to address the problems faced by internal migrants in accessing social security programmes in destination communities.

3. Measures to reduce migration costs and decentralize migration governance are required if low-income households are to benefit fully from migration. For instance, opening labour offices (that issue work permits or have help-desks) in the district centres could improve accessibility among migrant workers from low-income households and female migrants. This would make the migration process safer and strengthen migration governance. Such measures will also enhance the benefits of migration for the sending families - especially female family members.

For the countries of the Hindu Kush Himalaya (HKH) region, the importance of migration continues to be significant for livelihoods. Migration governance, therefore, is a critical priority (well-established). This chapter focuses on labour migration in the eight $\mathrm{HKH}$ countries. It explores the countries' overall migration experience and, where possible, highlights findings specific to mountain areas of the HKH.

Migration generally leads to changes in sending households and origin communities (established but incomplete). Assets are created; livelihoods are diversified. People in these households and communities gain better access to food, and they are more likely to have a safety net during a crisis. They are better able to access information. They acquire new knowledge and skills. Their social networks expand.

Remittances from migrants can have both positive and negative effects on the remittance-receiving households and origin communities, depending on context-specific factors (established but incomplete). Among these factors are the type of migration; the stage in the migration cycle; the asset base of the sending household; and the institutions and generic development conditions present in the origin community. 
Migration governance in the $\mathrm{HKH}$ comprises various national, regional and international policies and frameworks (well-established). Both national polices and regional and international instruments govern migration from and within HKH countries. The range and coverage of these policies vary significantly by country. Where international migration is seen as a significant issue - as in Bangladesh, India, Nepal, and Pakistan - it is governed by comprehensive policies and regulations and by nodal ministries.

Over time, major origin countries have increasingly recognized that migration can promote economic development - through decent wages for migrant labour, and also through the earning of foreign exchange (established but incomplete). Accordingly, some countries have acted in various ways to facilitate international migration (established but incomplete). These measures include establishment of a migration governance system; reducing migration costs; streamlining the remittance transfer process; assisting the reintegration of returnee migrants; and engaging the diaspora in national development.

Earlier, international migration governance was based on regulation and control (well-established). Governments have sought to manage recruitment, introduced restriction on movements of certain categories of workers (such as unskilled women). Some of the HKH countries have criminalised irregular and undocumented migration. Nonetheless, protection mechanism in both origin and the destination countries remained weak. In recent times some of the HKH governments have introduced new migration polices, framed new laws, created a separate ministry, among other actions (established but incomplete). For example, the Government of Nepal is trying to set a basic condition for a job contract whereby the employer is responsible for bearing the cost of the visa, ticket, and all other related expenses for the worker. The prospective migrant requires to pay only for services such as pre-departure orientation training, medical check-ups, the government-mandated worker's welfare fund and insurance.

Along with international migration, the HKH also experiences internal and cross-border migration. Urban centres are attractive to the migrants due to access to employment opportunities, urban amenities and services (e.g. education, electricity, healthcare and water), and opportunities for participating in the market. A lack of adequate education facilities, particularly opportunities for higher education, is a common reason for the youth to migrate to urban centres. Mountain communities are increasingly better connected with major market centres due to development in communication and transportation.

On internal migration, most HKH countries have public policies that reflect a strong sedentary bias: migration is perceived as a challenge to urbanization and planning processes. Discussion on internal migration in the context of urban development mostly concentrates on measures to reduce migration from rural to urban areas. This negative attitude towards internal migrants is often supplemented by a "sons of the soil" ideology (well-established).

Internal migrants to urban areas of HKH countries-who are relatively less educated, less skilled, and employed in the informal sector-experience exclusion of various nature (established but incomplete). Denied their rights, these internal migrants hardly enjoy social security such as public food distribution. They lack access to education and health care. Most importantly, they lack entitlement to housing at their migration destination, because they lack proof of identity and residence. In many cases they and their families end up living in informal settlements, with limited access to public amenities.

These forms of exclusion limit the benefits of rural to urban migration (well-established). Moreover, they create new risks for internal migrants and their families (established but incomplete). Accordingly, vulnerable internal migrants in HKH countries - who work in marginalised areas such as domestic work, construction, hawkers, and security guardsshould be supported with new social protection measures.

Many regional and international instruments are important for the governance of migration. The countries of the HKH have acceded to some of these instruments more than others. Recently, major sending countries in the regionAfghanistan, Bangladesh, China, India, Nepal, Pakistanhave joined regional consultative forums, such as the Colombo Process and Abu Dhabi Dialogue. A few of them have ratified the 1990 UN Convention on the Protection of All Migrant Workers and Members of Their Families. ${ }^{1}$ But none of these countries has ratified the ILO Conventions that are considered significant for migrants: the Domestic Workers' Convention (2011) (C189), ${ }^{2}$ the Migrant Workers (Supplementary Provisions) Convention (1975) ${ }^{3}$ (No. 143), and the Private Employment Agencies Convention (1997) ${ }^{4}$ (or C181) (well-established).

A significant development for the HKH in recent years has been the expansion of laws and policies against human trafficking (established but incomplete). Countries in the region have shifted away from a narrow definition of trafficking-limited to intended commercial sexual exploitation - to a broader interpretation that includes labour trafficking, slavery, bonded labour, organ trade, and drug trafficking. Laws in Bangladesh and Nepal have enabled the creation of special funds to support victims. Although gaps remain in

\footnotetext{
${ }^{1}$ http://www.ohchr.org/EN/ProfessionalInterest/Pages/CMW.aspx. ${ }^{2}$ http://www.ilo.org/dyn/normlex/en/f?p=NORMLEXPUB:12100:0:: NO::P12100_ILO_CODE:C189.

${ }^{3} \mathrm{http} / / / \mathrm{www}$. ilo.org/dyn/normlex/en/f?p=NORMLEXPUB:12100:0:: NO::P12100_ILO_CODE:C143.

${ }^{4}$ http://www.ilo.org/dyn/normlex/en/f?p=NORMLEXPUB:12100:0:: NO::P12100_INSTRUMENT_ID:312326.
} 
the implementation of these anti-trafficking laws and policies, the changes are welcome.

A challenge to analysing migration's effects across the HKH is that certain countries in the region, such as Nepal and Afghanistan, are mostly mountainous, whereas others are not. For example, only a small part of Bangladesh (the Chittagong Hill Tracts) belongs to the Himalaya mountain system. Whereas Nepal's experience — as a country - of short-term international contractual migration can generally be applied to its mountain areas, Bangladesh does not allow for such generalization: its national data may not reflect any conditions specific to the mountains (well-established).

\section{Migration and the Sustainable Development Goals}

Two Sustainable Development Goals (SDGs) directly pertain to migration governance. The first of these is SDG 8: Promote sustained, inclusive and sustainable economic growth, full and productive employment and decent work for all. Under this goal, Target 8.8 especially highlights the need to protect migrant workers: "Protect labour rights and promote safe and secure working environments for all, including migrants, in particular women migrants, and those in precarious employment." Other targets under SDG 8 with implications for migrants include 8.2, 8.5, and 8.10.

The second SDG with targets focused on migrants is SDG 10: Reduce inequality within and among countries. Two targets under this goal call for efforts specifically related to migration:

- Target 10.7-“Facilitate orderly, safe, regular and responsible migration and mobility of people, including through the implementation of planned and well-managed migration policies."

- Target 10.C--"By 2030, reduce to less than 3\% the transaction costs of migrant remittances and eliminate remittance corridors with costs higher than $5 \%$."

Beyond SDGs 8 and 10, migration will also be affected by initiatives under the SDGs to end hunger (Targets 2.4 and 2.C); to educate and develop skills equitably, including for women and the marginalized (Targets 4.4, 5.A, 13.B); to promote inclusive cities, with safe, affordable housing and secure living conditions (Targets 11.1. and 11.5); and to meet a range of other development objectives (Targets 1.5, 6.4. 6.5, 6.6, 9.1, 9.C, 13.1).

Households in the HKH adopt migration as a strategy to increase their income, diversify their livelihoods, seek a better life, and manage risks arising from various stresses and shocks. As countries in the region pursue their development priorities, they should emphasize programmes that provide for social inclusion, social protection, and adaptation planning. Countries can unlock the potential of migration by reducing its risks - protecting households against the possibility that migration will erode their assets. Other recommended steps are to make the policy response on human mobility comprehensive; to enable migrants to benefit from government development initiatives, including the response to climate change; and to bring remittances into development planning, exploring how they may enhance capacity in communities of origin.

\subsection{Labour Migration in the HKH: A Challenge and Opportunity for Inclusive Growth}

Migration has become an integral part of current global development process. As per United Nations Department of Economic and Social Affairs (2013a, p. 25) in 2005, 763 million people have moved within their own countries and another 232 million people have moved outside their countries of origin (United Nations Department of Economic and Social Affairs 2013b). This chapter is on internal and international labour migration from the Hindu Kush Himalayan (HKH) region. Across the HKH countries population movement is widely perceived as a challenge. However, there is a growing understanding that it can also open up new opportunities for development for those who migrate, their left behind families, communities of their origin as well as to the national economies of origin and destination areas and countries. Emerging research shows that a large number of climate change affected households in this region have been using labour migration as one of the many adaptation tools. Remittances sent by the migrants are being used in disaster risk reduction. In the past mainly men migrated for work, and women were left behind, or, accompanied the men as spouse. Since the beginning of the new millennium, an ever increasing number of women are participating in labour migration in some of the HKH countries. This chapter attempts to understand the dynamics of labour migration in this region. One of the major goals of the chapter is to consolidate the current state of knowledge on migration, and where possible, collate mountain-specific information on migration. It concentrates on three areas of migration research: drivers, consequences, and governance of labour migration.

There are several challenges in analysing migration in the HKH region. For one, most parts of Afghanistan, Bhutan, 
and Nepal are considered to be within the HKH whereas only a small part of Bangladesh belongs to the Himalaya. Therefore, while the experience of short-term international contractual migration of Nepal, for example, can be generalized for the mountain and mid-hill areas of the country, such a generalization is not possible in the Chittagong Hill Tracts of Bangladesh. Unlike other parts of Bangladesh, three districts of Chittagong Hill Tracts (i.e., Bandarban, Khagrachhari and Rangamati) hardly had any experience of short-term international migration. In the case of China, India, and Myanmar, different patterns and characteristics of population movements are observed in different parts of mountain regions of these countries. Hence, it is challenging to meaningfully analyse the implications of labour migration, particularly for the areas belonging to the HKH region. Absence of mountain specific data in nationally representative sample surveys is another challenge. Data that are generated at the country level are not gathered following common standardized definition and method. This limits the scope of cross-country comparisons. Besides, the available migration data from country level census is unlikely to cover circular and temporary migration. Though the data on international remittances have been improving over the past decade, data on domestic remittances remains scarce and scattered in several HKH countries.

The chapter is divided into five sections including this introductory one. Section two presents the country-specific migration patterns. Section three looks into what drives labour migration from the mountain areas of these countries. Section four presents consequences of labour migration for mountain communities. Section five analyses the governance of labour migration in the $\mathrm{HKH}$ region. Section six draws some key conclusions.

\subsection{Diverse Trends, Consistent Importance of Migration}

This section provides a brief country-specific overview of the diverse patterns of migration and remittance flow in the HKH. All HKH countries, except Afghanistan and Bhutan, show an increasing stock of emigrants (see Fig. 15.1). Figure 15.2 shows that the countries of the $\mathrm{HKH}$ region received a considerable amount of remittances. There has
Fig. 15.1 Changes in the emigrant stock of the $\mathrm{HKH}$ countries (Source United Nations Department of Economic and Social Affairs 2015; http://www. un.org/en/development/desa/ population/migration/data/ estimates2/estimates15.shtml)

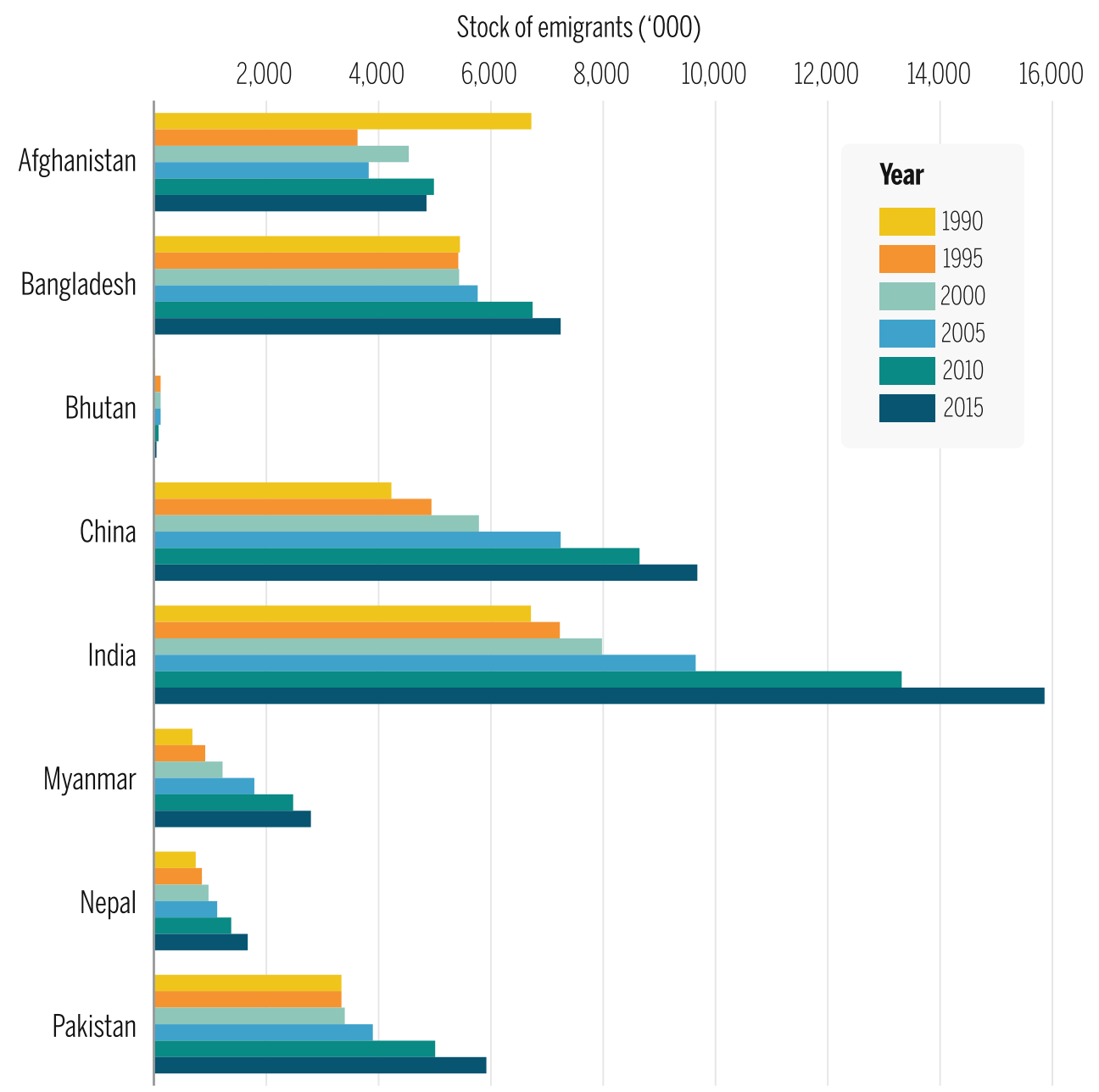


Fig. 15.2 International remittances received by $\mathrm{HKH}$ countries in 2016 (in Million US Dollar) (Source World Bank 2017; https://data.worldbank.org/ indicator/BM.TRF.PWKR.CD. DT)

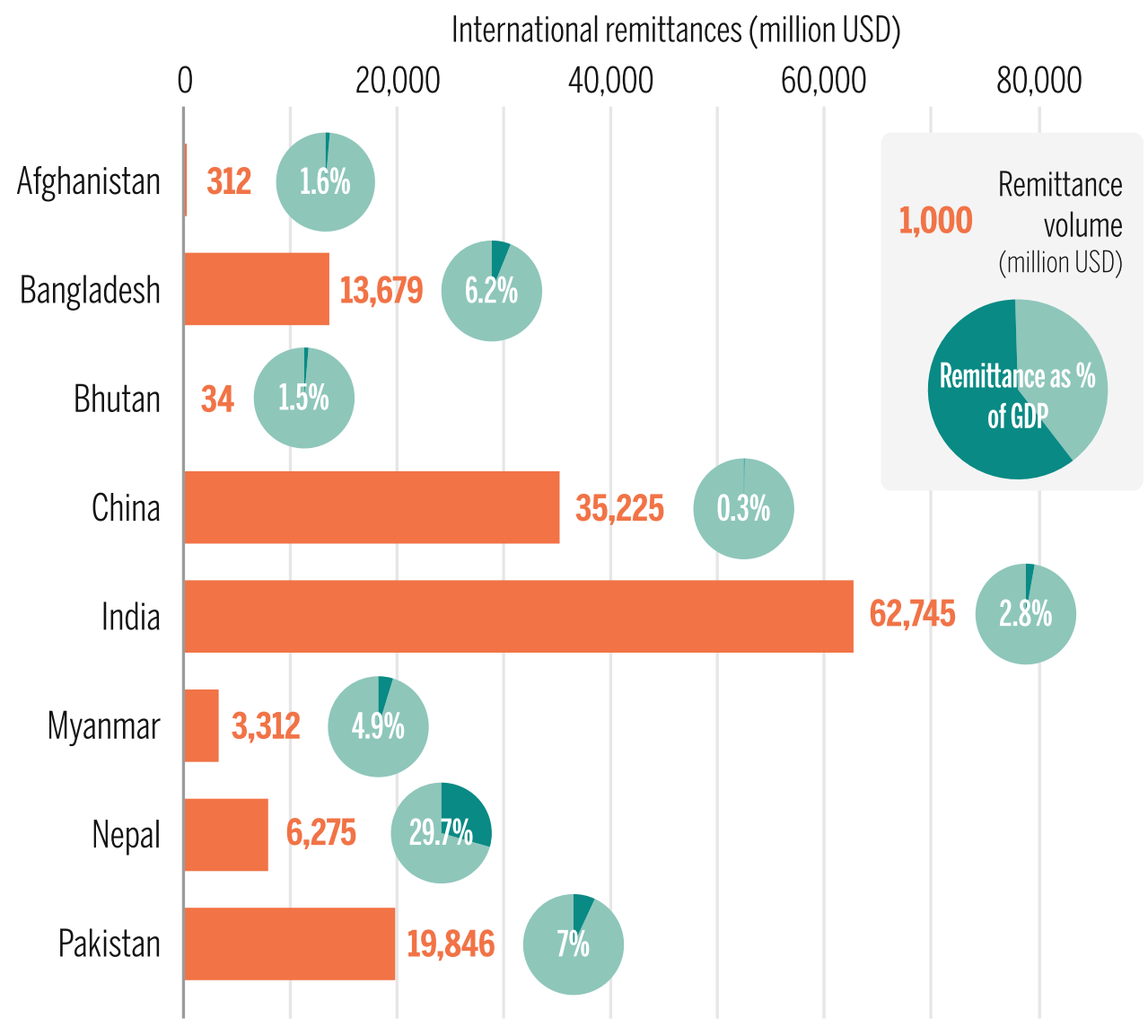

been a sharp rise in remittances in countries like Bhutan and Myanmar in recent years (see Fig. 15.3).

\subsubsection{Afghanistan: Mixed Flows}

Afghanistan's migration patterns are perhaps the most unique across the world. The country in its recent history produced one of the highest number of refugees and internally displaced

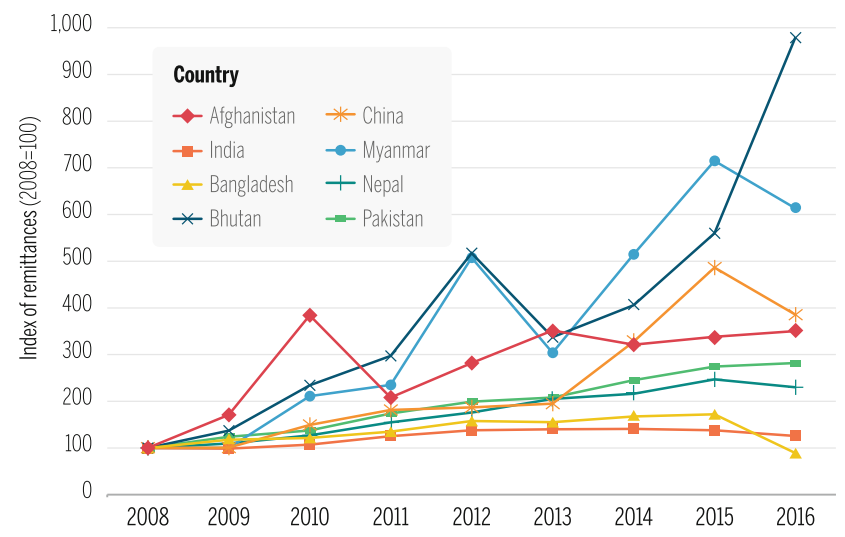

Fig. 15.3 Changes in the index of international remittances received by HKH Countries in $2016(2008=100)$ (Source World Bank 2017; https://data.worldbank.org/indicator/BM.TRF.PWKR.CD.DT) persons, while it has also become the largest recipient of returnees (Norland 2016). The history of internal, regional and international displacement in Afghanistan is directly linked to its political, economic and social formations, and in particular, it is linked with protracted years of war and conflict. Since 1979 when Afghans left the country due to Soviet invasion, the net negative migration rate was $56.7 / 1000$ persons; between 1990 and 1995 it reversed to positive net migration of 44.4/1000 persons, and under the Taliban regime (1995-2000) this rate sank below parity to $-6.5 / 1000$ persons (International Organization for Migration 2014). Over 320,000 Afghans returned in 2016 alone. The country has become the largest recipient of returnees in comparison to all European and South Asian countries put together (Norland 2016). There are 2.5 million Afghan refugees still living in Pakistan; of them 1 million are registered, and 1.5 million are unregistered (or undocumented) and hence cannot access United Nations High Commissioner for Refugees cash grants or get verified as refugees for getting support (Ahmadi and Lakhani 2017). There are 950,000 Afghan refugees in Iran and returns from Iran during 2016 were 436,236 undocumented and 2305 documented (Ahmadi and Lakhani 2017). Many of returnees from both Iran and Pakistan are considered 'voluntary returnees'. However, in reality the repatriations are often coercive with refugees left with little choice to remain 
(Ahmadi and Lakhani 2017). Despite this fact, Pakistan still remains the first destination for the Afghan refugees. Over 1.2 million persons are displaced internally. The majority of internally displaced Afghans come from four provinces: Kundoz (northern), Uruzganan and Helmand (southern) and Farah (western). During 2016, more than half of the IDP population (56\%) were children (Bjelica 2016). Afghanistan is also the second largest source country for refugees globally. There are 2.7 million Afghan refugees across the world (United Nations High Commissioner for Refugees 2017).

\subsubsection{Bangladesh: Moving Within and Beyond}

With a population of 160 million, Bangladesh is the most densely populated country of the HKH region. In 2015, 90 out of every 1000 people moved from rural to urban areas (Bangladesh Bureau of Statistics 2016). Bangladesh is rapidly becoming urban. Rural-urban population movement is one of the major reasons behind such urbanization. Seasonal migration is also extremely common in Bangladesh. However, there is little data on this.

Since 1970 Bangladesh has been participating in the short-term labour market of the Gulf and other Arab countries, and Southeast Asia. Traditionally only men participated in this market. Since the lifting of the ban in 2003, the number of female migrants also started increasing. In 2016 around 750,000 persons migrated overseas for employment. Sixteen percent of them were women. Bangladeshi workers mostly get jobs under unskilled and semi-skilled categories. However, as the Bureau of Manpower Employment and Training of the Government of Bangladesh considers domestic workers as skilled, government statistics show quite a high proportion of skilled workers. Bureau of Manpower Employment and Training data indicate that among the total migrant workers who went abroad in 2016, 43.1\% were skilled, $40.08 \%$ were less skilled, 15.83 were semi-skilled, and $0.61 \%$ were professionals (Bureau of Manpower Employment and Training 2016). The education level of those who participate in the short-term international labour market is lower than that of people who migrate from rural to urban areas for work (Siddiqui and Mahmood 2015). Eighty-one percent of the total workers who migrated in 2016 moved to Gulf and other Arab countries, and the remainder migrated to Southeast Asia. Oman, Saudi Arabia, Qatar, Bahrain, and Singapore were the major destinations of Bangladeshi migrant workers in 2016 (Bureau of Manpower Employment and Training 2017). However, international short-term migration from three hill districts of the Chittagong Hill Tracts region is almost non-existent. The flow from Bandarban, Khagrachhari and Rangamati constituted $0.12 \%, 0.07 \%$ and $0.06 \%$ respectively of the total flow in
2016. (Refugee and Migratory Movements Research Unit 2017). More importantly, people from these three districts who participate in migration are from the Bengali community; the ethnic hill population does not have representation in international migration. Since the Peace Accord of 1997, internal labour migration from the CHT has been increasing. Indigenous male population from this area mostly migrate to export processing zones of Chittagong Division to work in the manufacturing sector and to the mega city of Dhaka where they have created a niche as security guards. Women participate in the manufacturing sector and domestic work.

Bangladesh is a major remittance receiving country. As per World Bank data from 2014, its position was 10th in the world (The World Bank 2016a). The flow of remittance dropped substantially in 2016. That year Bangladesh received USD 13.6 billion. The figure was almost $11 \%$ less than in the previous year (Bangladesh Bank 2017). A similar decline in remittance inflow was experienced by India and Nepal. Drop in oil prices, low economic growth in the Gulf region, and depreciation of Euro and Pound Sterling have been identified as major reasons (The World Bank 2016a). Saudi Arabia is still the most important source of remittance for Bangladesh, followed by the UAE, USA, and Malaysia.

\subsubsection{Bhutan: A Closed Mountain State?}

Bhutan has an estimated population of 764,667 people of whom $30.6 \%$ live in the urban areas and the remainder continue to live in the rural areas (Ministry of Labour and Human Resources 2015). A study by the Ministry of Agriculture and Forest $(2013$, p. 1) estimated that $21.4 \%$ of the total population are migrants. Between 2000 and 2013, the migration rate in Bhutan was estimated to be $10.9 / 1000$ people (Ministry of Agriculture and Forests 2013). One of the key issues facing Bhutan is the migration of people from rural to urban areas. It has been reported that nearly $65.6 \%$ of rural households have at least one member who has migrated to an urban centre (Ministry of Agriculture and Forests 2013). Urban centres in Thimphu dzongkhag were destinations of one-third of the migrants. Previous research has shown that lack of employment opportunities, limited access to education, small landholding, limited access to market, and limited access to other services (e.g. health and motor-roads) are the major reasons why people leave their rural homes (Ministry of Agriculture 2006; Ministry of Agriculture and Forests 2013). Out-migration from Bhutan is minimal and consists mostly of Bhutanese students studying abroad. Bhutan also receives immigrants, particularly temporary migrant workers from India, who mostly work in the construction sector (Ministry of Labour and Human Resources 2015). 


\subsubsection{China: Inter-provincial Migration}

China's rapid development and urbanization has induced large numbers of rural residents to migrate from their homes in the countryside to urban areas (Hu et al. 2008; Ministry of Human Resources and Social Security 2013; Wen and Lin 2012). The 2016 Migrant Worker Monitoring Survey Report shows that there were 281.7 million migrant workers, which account for about three quarters of its rural labour force (National Bureau of Statistics of China 2017). Among those migrant workers from rural areas, $45 \%$ migrate to places within their own provinces whereas the rest migrate outside of their provinces. However, there are significant variations across regions. The same report reveals that eastern and northeastern regions see $82 \%$ and $77 \%$ of their migrant workers migrate within provinces. In contrast, these numbers are $48 \%$ and $38 \%$ for western and central regions, respectively. ${ }^{5}$

Disaggregation by gender shows that women account for $35 \%$ of the total migrant workers with the rest $65 \%$ being men. Among those who migrate within their provinces, the share of women is $37 \%$, five percentage points higher than the share of women among those who migrate outside their provinces (National Bureau of Statistics of China 2017).

If we look at the migrant workers by birth cohorts, the National Bureau of Statistics of China (2017) report shows that while the share of the 21-30 and 41-50 cohorts of migrant workers are $27 \%$ and $29 \%$ respectively, the percentages are $19 \%$ and $22 \%$ for 50 and above and $31-40$ cohorts respectively. Only a small share (3\%) of migrant workers fall into the 16-20 cohort.

As with the rest of the developing countries in this region, it is difficult to get a good estimate of the total volume of remittances sent home by migrant workers. According to Gong et al. (2008), migrants from rural areas in China sent about USD 30 billion remittances in 2005 .

In China, the pattern of migration in its mountainous regions looks somewhat different than the pattern in China as a whole. Taking Sichuan province in the southwest part of China, for example, a recent survey conducted in rural Sichuan by Zhang et al. (2017) shows that in 2015, $79 \%$ of rural labour force had found some off-farm employment. Of

\footnotetext{
${ }^{5}$ The east region includes 10 provinces/municipalities: Beijing, Tianjin, Hebei, Shanghai, Jiangsu, Zhejiang, Fujian, Shandong, Guangdong and Hainan. The northeast region includes 3 provinces: Liaoning, Jilin and Heilongjiang. The central region includes 6 provinces: Shanxi, Anhui, Jiangxi, Henan, Hubei and Hunan. The west region includes 12 provinces/autonomous regions/municipalities: Inner Mongolia, Guangxi, Chongqing, Sichuan, Guizhou, Yunnan, Tibet, Shaanxi, Gansu, Qinghai, Ningxia and Xinjiang. Statistics show that in 2015, the per capita GDP in the east region ranks the first at 71,013 Yuan, followed by the northeast region $(52,814$ Yuan), the central region (40,274 Yuan), and the west region (39,056 Yuan) (National Bureau of Statistics of China 2016).
}

them, 24\% migrated within Sichuan province while the rest migrated to places outside of Sichuan. As for the gender composition of those migrants, $49 \%$ are women with the rest $51 \%$ being men. When it comes to age, while the share of the 50 years old and above and 41-50 cohorts of migrant workers are $31 \%$ and $26 \%$ respectively, the percentages are $18 \%$ and $17 \%$ for the $31-40$ and $21-30$ cohorts respectively. Almost $8 \%$ of migrant workers fall into the 16-20 cohort. When examining remittances, the survey reveals that $66 \%$ of migrants sent remittances home. Among those who did send remittances, an average migrant sent 20,463 yuan (about USD 3,200) home in 2015.

\subsubsection{India: Long-Distance Internal Migration}

Internal migrants account for 37\% (453 million) of the country's population as per the 2011 census of India. Compared to internal migration, the stock of emigrants was 15.5 million i.e., about $1.2 \%$ of India's population (United Nations 2015). Increasing urbanization and development of growth centres in urban locations are contributing to internal migration in India. Rural to urban migration has been contributing substantially to urbanization and the rural-urban demographic composition of households. The rural households are increasingly dependent on urban resources and non-farm jobs as urbanization has been shaping rural-urban relationship through various flows of goods and services, financial flows, and movement of people. Several parts of the Indian Himalayan region have been urbanizing fast, which influences mobility of labour (Lusome and Bhagat 2013; Mohanty and Bhagat 2013). Increasing urbanization is also accompanied by a change in mobility among women. Although women predominantly migrate due to marriage and family related reasons, a significant proportion of them are now joining the workforce after migration (e.g. domestic work and construction sector). A large number of placement agencies are involved in the recruitment process (Neetha 2003; Srivastava 2012).

Emigration from the Indian Himalayan region is lower compared to that from the plains. The emigration is largely influenced by a higher socio-economic status, a network of emigrants and emigration infrastructure (Bhagat et al. 2013). On the other hand, inter-state migration from the Himalayan region is higher than that from the plains.

India is the world's largest remittance recipient. As per the World Bank, in 2014 India received USD 70 billion, which declined to USD 62 billion in $2016 .{ }^{6}$ The survey-based estimates show that household remittances sent by internal migrants in 2007-2008 were twice those sent by

${ }^{6}$ http://data.worldbank.org/indicator/BX.TRF.PWKR.DT.GD.ZS. 
international migrants for the same period (National Sample Survey Organization 2010). Further, in the Indian Himalayan region a relatively higher proportion of households (12\%) received remittances compared to the non-Himalayan part of the country (9\%), according to National Sample Survey Organization 64th conducted in 2007-2008.

\subsubsection{Myanmar: Through the 'Open Doors'}

Migration has been a prominent feature of Myanmar's socio-economic makeup for a long time (e.g., Andrus 1948). Nonetheless, the scale and dynamics of migration increased in the past couple of decades due to political and economic changes both within the country and in neighbouring countries. The 2014 Myanmar Population and Housing Census (Department of Population 2015, 2016) counted over 9.39 million internal migrants, and based on the number of international migrants counted during the Census, it was estimated that 4.25 million Myanmar nationals live abroad. Together, they represent $25 \%$ of Myanmar's total population of 51 million. The Census revealed that recent internal movement revolved around Yangon, Myanmar's former capital and the largest city, and suggests that expanding industrial development is a powerful instrument influencing the direction of migration. Overall, the eastern part of Myanmar with geographical proximity to Thailand and China experienced high levels of recent in-migration, while the central and western part of Myanmar where poverty is more widespread experienced net-population loss from migration.

When it comes to internal migration, female migrants outnumber male migrants with $53 \%$ of migrants being female. While females migrated to follow family (49\%), for employment $(23 \%)$ or for marriage $(19 \%)$, employment was the largest most common reason behind male migration $(47 \%)$. The vast majority of recent migrants concentrated at ages around 25-30 years, and they were generally better educated than non-migrants, and were less likely to be unemployed (Department of Population 2016).

Of the estimated 4.25 million Myanmar nationals living abroad, over $70 \%$ are reported to have migrated to Thailand, followed by Malaysia (15\%), and China (5\%) (Department of Population 2015). $75 \%$ of Myanmar migrants in Thailand come from the eastern part of Myanmar, which creates a vacuum in the labour market in this region, and this in turn attracts in-migration of internal migrants from central and western Myanmar. Origin states and regions of migrants going to other destination countries are more diverse, with Yangon being the largest source region. Contrary to internal migration, there are fewer female international migrants (39\%); however, this varies from one destination country to the other (e.g., 97 and $81 \%$ of Myanmar migrants to South Korea and Malaysia are male, while $51 \%$ to Singapore are female).
It is difficult to have a good sense of the total volume of remittances to Myanmar due to the predominantly informal nature of the transfer. The World Bank estimated the total remittances to Myanmar in 2015 to be USD 3.2 billion, which contributes to $5 \%$ of national GDP (The World Bank 2016b). The Ministry of Labour, Employment and National Security (MoLES) was reported to have estimated the annual official and unofficial inflow of remittances at USD 8 billion in 2015 (Kyaw 2015). International Organization for Migration estimated that USD 2.17 billion were sent back from Thailand to Myanmar in 2012-2013, of which $83 \%$ were sent through unofficial channels (Ito 2016).

\subsubsection{Nepal: A Remittance Economy?}

As reported in the Nepal Living Standards Survey (NLSS) of 2010/11, 53\% of households in Nepal have at least one absentee living within or outside the country (Government of Nepal 2011, p. 133). As per the 2011 Census, this indicates more than two-fold increase in the number of Nepalis living away from the country from 2001 to 2011 (Government of Nepal 2012). The figures for labour migrants are equally significant with a total of 2,723,587 labour permits issued by the Department of Labour and Employment from 2008/2009 through 2014-2015 (Government of Nepal 2016). While men account for approximately $96 \%$ of the labour permits issued between 2008 and 2015, the number of females seeking employment has increased by 2.5 times over the same period (Government of Nepal 2016, pp. 7-8). According to data available at the Department of Foreign Employment (DoFE), $47 \%$ of migrants are from the age group 26-35 followed by age group 36-45 (26\%). There is no significant variation in the age categories of male and female migrants (Government of Nepal 2016).

In terms of destination, the data available from DoFE does not include migrant workers going to India since labour permits are not required for India, and to the Republic of Korea since workers migrate through the government-togovernment agreement (Government of Nepal 2016). However, if one were to include these countries, the 2011 census figures indicate that the percentage of Nepalis going to India is equal to those headed towards the Gulf (approximately 38\%) followed by the ASEAN countries (13\%) (Government of Nepal 2013). The proportion of Nepali migrants going to India has however considerably decreased, from $77.2 \%$ in 2001 to $37.6 \%$ in 2011 (Government of Nepal 2014). Primary destinations include Malaysia and the Gulf countries, which account for $85 \%$ of the labour permits issued during the same period (Government of Nepal 2016). There is however a slight variation in the destination countries for women and men with a higher percentage of men going to Malaysia, Qatar, and Saudi Arabia, where the demand for construction workers is 
higher, while the proportion of females is higher for countries like the UAE and Kuwait, where women are mostly employed as domestic workers (Government of Nepal 2016).

Overall, this increasing trend of Nepalis migrating for employment abroad has meant that the percentage of remittance-recipient households has increased from $23 \%$ in 1995-1996 to 56\% in 2010-2011 (Government of Nepal 2011). Currently, remittances contribute about $30 \%$ of the country's GDP - a significant increase from $10.9 \%$ in 2003/2004 (Nepal Economic Forum 2014), making Nepal the third-highest recipient of remittances as a share of GDP among all countries in the world (The World Bank 2014). Remittances to Nepal rose dramatically in response to the earthquake, growing by $27.6 \%$ in three months from April to June 2015 compared to the same period the year before. However, following this peak, inflow of remittances has slowed down registering a single digit growth by January 2016. Between February and April 2016, remittances have contracted by $5.3 \%$ (in USD terms) compared to the same period of the previous year (The World Bank 2016c).

\subsubsection{Pakistan: Diverse Flows}

Labour migrants moving internally in Pakistan account for approximately $2 \%$ of the population - a rate that has been roughly constant over the last twenty years. ${ }^{7}$ Given the country's size, however, this suggests a stock of 36 million migrant workers at any given period of time. The stock of international migration is much smaller at 9.6 million (19712016). ${ }^{8}$ That being said, the flow of international migration has seen a strong uptick since 2005. The number of workers emigrating annually has steadily increased from roughly 150,000 in 2005 to roughly 850,000 in $2016 .^{9}$ In terms of areas of origin, nearly $45 \%$ of emigrants are from the 10 HKH districts of Abbotabad, Bannu, Lower Dir, Kohat, Mansehra, Mardan, Mirpur, Muzaffarabad, Poonch, and Swat. In terms of gender, only $4 \%$ of internal migrants are women while the gender composition of international migrants is unknown (Pakistan Bureau of Statistics 2011).

In 2016, $90 \%$ of international flows were towards just two countries, UAE and Saudi Arabia, popular destinations for Pakistani workers since the 1970s. Anecdotal evidence suggests that these flows generally consist of young single men. Moreover, the skill levels of the emigrants also appear to be improving over the years, suggesting an impact on the magnitude of the remittances (Amjad et al. 2015). In fact,

\footnotetext{
${ }^{7}$ Pakistan Bureau of Statistics, Labour Force Surveys various rounds. ${ }^{8} \mathrm{http} / / /$ beoe.gov.pk/reports-and-statistics. This is an overestimate since it is a sum of outflows over the years. No data is available on return migration.

${ }^{9}$ Ibid.
}

remittances have increased from roughly USD 1.5 billion in 1998 to USD 13 billion in 2012, i.e. from $2.0 \%$ (1998) of GDP to $6.2 \%$ (2012). Perhaps more importantly, data from 2012 suggest that remittances constitute roughly half of the exports of goods and services and thus provide critical balance of payments support (Amjad et al. 2015).

Few studies have looked into the impact of remittances at the household level. Ahmed et al. (2010) show that the mean expenditure of a migrant household is $41 \%$ higher than that of a non-migrant household. Remittances have a positive effect on the shares of household expenditures on food, education, clothing and recreation. The highest increase is in the expenditure share on durables at $74 \%$. The budget share of education increases only by $2.9 \%$. Moreover, the impacts of remittances on household welfare were strongest in rural rather than urban Pakistan.

\subsection{Diverse Trends in Migration}

Migration decision depends upon individual, household, and community characteristics, interplay of intervening obstacles, and influence of demographic, economic, environmental, political and social factors. Due to complex interactions between these drivers, it is rarely possible to identify individuals whose migration decision was solely influenced by one particular driver. Despite the existence of migration drivers, whether migration occurs or not depends on a series of intervening factors and personal household characteristics (Black et al. 2011).

\subsubsection{In Search of a Better Life}

The economic prospects of the plains and urban areas contrasts with the slower economic development of mountainous areas; with livelihood opportunities in the latter, particularly in the rural areas, generally limited to primary sector (Kollmair and Banerjee 2011). The farm sector in this region is constrained by low productivity and underemployment. It is undermined by environmental shocks and stresses, land degradation, land-use regulations, price fluctuations, lack of access to formal credit and lack of market access (Bohle and Adhikari 1998; Huo et al. 2006; Liang and Ma 2004; Olimova and Olimov 2007). The urban and peri-urban areas provide easier access to non-farm income opportunities, especially the informal sector, to rural households. In Bhutan, internal migration flows primarily to the economic hubs of the country-Paro, Chukha, and Thimphu - from the rural areas (Ministry of Agriculture and Forests 2013; Ura 2013). Similarly, in Afghanistan, Kabul receives the largest number of migrants (mostly men, aged 15-45) followed by Jalalabad et al. (Opel 2005). 
Respondents of two Chittagong Hill Tracts districts of Bangladesh identified a wide range of economic reasons from low wage in the area of origin and better income opportunities at the destination to desire for economic betterment and coming out of poverty (Siddiqui and Billah 2014). Unlike in most other developing countries, in Bhutan people migrating to urban areas are relatively well-off and have a certain level of qualification (Ura 2013). In Afghanistan, the deterioration of the overall security situation as well as lack of job opportunities across the country has also led to an increase in migration from the villages to urban centres (Opel 2005). People who leave rural areas find limited opportunities in the urban centres due to their limited capacities. Despite this, the rural-urban migration in Afghanistan is rising rapidly (Government of the Islamic Republic of Afghanistan 2015).

Migration outcome is also influenced by pre-migration wealth and skill level. Rich households have more choices with respect to migration destination. Those who migrate to developed countries belong to the rich and middle-income households or to the highly skilled category. A majority of those who migrate to the Gulf region, other Arab countries and Southeast Asia to do unskilled work are not from rich or middle-income households but they are mostly from households above the poverty level. Poorer people are likely to opt for rural-to-rural and rural-to-urban, seasonal and temporary internal migration with lower salaries and wages and thus low remittances.

\subsubsection{Better Educated, Better Connected}

Education has emerged as an important social determinant of migration. The lack of adequate education facilities and limited access to better education was the most commonly cited reason for leaving rural homes in Bhutan (Ministry of Agriculture 2006; Ministry of Agriculture and Forests 2013). The same is true with mountainous areas of upper Myanmar where there is critical shortage of education infrastructure coupled with ongoing instability; as a result, larger proportions of people migrate for education (Department of Population 2015). At the same time, most of the migrants from this region have some form of education. The literacy rate of the migrating population in Bhutan is considerably higher than the national average (Ministry of Agriculture 2006). In Nepal, Massey et al. (2007) found that each additional year of schooling raised the odds of long distance migration by a highly significant $5 \%$.

Migration requires certain resources to meet the costs; therefore, it may not be a feasible strategy for all households. In Uttarakhand state of India, persons belonging to socially dominant castes, which have better access to education, financial resources and social networks, are more likely to migrate (Jain 2010). Further, as the experience of Nepal suggests, the choice of destination is determined by several factors such as the socio-economic status of households (Bhandari 2004; Jain 2010), stage in migration cycle, type of aspired job, labour requirements at home, familiarity with destination, and migrant networks (Bruslé 2008). Social networks based on familial affiliation to a social or cultural group influence people's decision to migrate and choice of destination. These networks support migration by extending loans, assisting with logistics, arranging jobs and accommodation, and providing emotional support to the migrant or the family left behind. Benz (2016) reported that assistance from one generation of migrants from Gilgit-Baltistan allowed subsequent migrants to find employment or to enroll in a higher-level education. In a study in Chittagong Hill Tracts in Bangladesh by Siddiqui and Billah (2014), $37 \%$ of the respondent households reported that although they wanted to send family members to seek work elsewhere, they could not since they did not have information on work opportunities outside the village. They also did not know anyone at the destination (Siddiqui and Billah 2014).

Though mountain communities are increasingly better connected to large market areas of the region due to development in communications, electrification, and transportation (see Benz 2016; Kreutzmann 2004; Olimova and Olimov 2007) but the relationship of this progress to migration is still ambiguous. Migration may be a consequence of the structural changes in mountain areas. Urban centres are attractive to potential migrants because of access to employment opportunities, access to urban amenities and services such as education, health, electricity and water, and opportunities for participating in the market. According to the Ministry of Agriculture (2006), rural to urban migration is a significant contributor to the urbanization process in Bhutan as $72 \%$ of all urban dwellers could be classified as migrants from rural areas. Increased urbanization has been a significant cause of rural to urban migration in the Indian Himalayas (Lusome and Bhagat 2013; Mohanty and Bhagat 2013). In Afghanistan, though, Ghobadi et al. (2005) found households that resided in communities with more irrigated land and services (e.g. markets, public transportation or health facilities) showed lower probability of migration.

\subsubsection{Young Men and Women on the Move}

Demographic factors such as age, gender, and household composition influence the migration process. Since the establishment of the current political setting in 2001, patterns of international migration from Afghanistan have changed in terms of gender and age group. For instance, most migrants from Afghanistan to the United Kingdom in 2001 were young men in their 20s and 30s. In 2006 the number of 
unaccompanied minors increased. Although the majority of Afghan migrants are still young males, the number of female migrants - who are married to Afghan residents in other countries-has increased since 2008 (Hall 2013). Ministry of Agriculture and Forests (2013) reports that the economically and physically active population migrated the most in Bhutan. Ura (2013) indicates that $61.2 \%$ of migrants in Bhutan comprised young people in the age group of 10 34 years, majority of whom were men. Although men still dominate migration flows in China, the gap between male and female participation in the migrant labour force is narrowing, especially among cohorts aged between 16 and 20 years old ( $\mathrm{Li}$ et al. 2013). Male migrants accounted for over $95 \%$ of the labour permits issued by Department of Foreign Employment in Nepal between 2008 and 2015 (Government of Nepal 2016). A study in Chitwan district of Nepal by Massey et al. (2007) reports that while the likelihood of local mobility and long-distance migration declined with rising age; this effect was more pronounced for the former rather than the latter. The low participation of women in labour migration in this region (especially Afghanistan, India, Nepal, and Pakistan) can be explained by women's lack of education and exposure to migration opportunities as well as the traditional division of labour by household, which requires women to oversee domestic responsibilities (Hoermann et al. 2010). Marriage is a major reason for female migration in the entire $\mathrm{HKH}$ region. Gender and other forms of social inequities are some notable drivers of migration; severe exclusion is one of the factors that compel people to migrate. A few studies on female migration have identified family violence and/or broken homes as a reason for women's migration from Nepal (Bhadra 2013; International Labour Organization 2015). In Bangladesh some women migrated to accumulate resources to bear the cost of their own or their family members' wedding including dowry (Siddiqui 2008).

\subsubsection{States Policies Shape Migration}

States policies seek to either explicitly or implicitly control migration, or may have an independent effect on whether people move or not. A hukou classifies China's citizens as either rural or urban residents. Without an urban hukou, migrants and their families have limited access to urban public services, including housing, healthcare, social security, and above all, education. The education of migrant children has become one of the major challenges for both migrant families and the Chinese education system. In China, public schools are supposed to provide free education to children. However, the free education is only guaranteed to children whose hukou matches the school's location (Fu and Ren 2010). Since migrant children in cities still retain their rural hukou, they are allowed to enroll in urban public schools only if there is available space. In many cases migrant parents can only enroll their children if they are willing and able to pay steep out-of-district tuition fees. Though in a case study in Uttarakhand state of India, Jain (2010) suggests that Mahatma Gandhi National Rural Employment Guarantee programme had reduced the need for seasonal migration, mainly among unskilled or less educated persons, the impacts of this programme on migration remains ambiguous. The Government of Nepal in August 2012 placed another ban on women less than 30 years of age from migrating abroad to work as domestic help. The ban was lifted in 2016, but on the condition that the minimum wage requirements for domestic workers have been met (Government of Nepal 2015; International Labour Organization 2015).

In turn, other policies seek to facilitate migration. The open border between India and Nepal was recognized by the India-Nepal Treaty of Friendship of 1950. This permitted the citizens of either country a visa-free entry into the other country and stay as long as desired (Adhikari et al. 2008; Subedi 1991). For the poor, acquiring official documents such as a passport could often be an insurmountable challenge (Hoermann and Kollmair 2008). However, the open border between India and Nepal allows them to use other national identification documents. For example, an Indian citizen could use any one of the following documents to enter Nepal: Driving license with photo, election commission card with photo, identity card issued by Embassy of India in Kathmandu, identity card with photo issued by Sub-Divisional Magistrate or any other higher ranking officials, passport, photo identity card issued by a government agency or ration card with photo. ${ }^{10}$ A Nepali citizen could establish his/her identity as a Nepali citizen using a citizenship certificate, limited validity photo-identity certificate issued by Nepalese Mission in India passport or voter's identification card. ${ }^{11}$

There is no legal regime for labour migration between India and Bangladesh. However, migration for work does take place between the two countries, but flows are mostly irregular. Those who migrate from Bangladesh are less skilled workers. Men mostly work as agricultural and day labourers, waste collectors, rickshaw pullers, and cleaners; women mostly work as domestic workers. Those who come to work in Bangladesh from India are mostly skilled workers. They work in the garment and other manufacturing sectors as well as health and service sectors (Siddiqui 2006). There is no authentic data available on Indians working in Bangladesh and Bangladeshis working in India. The issue of

\footnotetext{
${ }^{10} \mathrm{https}: / /$ www.nepal.gov.np/NationalPortal/view-page id=131.

${ }^{11}$ https://boi.gov.in/content/nepalese-passengers.
} 
migration between these two countries is highly politicised. India does not figure in the remittance inflow data of the central bank of Bangladesh (Bangladesh Bank 2017).

\subsubsection{Migration: A Strategy for Climate Change Adaptation}

Migration patterns are shaped by interaction between demographic, economic, environmental, political, and social drivers (Intergovernmental Panel on Climate Change 2014). Mere existence of these migration drivers does not ensure migration as an outcome, which is determined by intervening factors as well as household and personal characteristics (Black et al. 2011). Though climatic events and trends are likely to influence these patterns (Intergovernmental Panel on Climate Change 2014), it is extremely complex to establish a causal relationship between environmental change (including climatic stressors) and migration. Moreover, various forms of human mobility (e.g. displacement, migration, and relocation) could be observed in the communities affected by disasters and environmental change. Some case studies (Banerjee et al. 2011; Bohra-Mishra and Massey 2011; Massey et al. 2007, 2010; Mueller et al. 2014; Shrestha and Bhandari 2007; Siddiqui and Billah 2014) specifically focus on the relationship between environmental change and migration in the HKH region. Migrant and non-migrant households of two Chittagong Hill Tracts districts highlighted 28 types of environmental and climatic hazards that have led some households or their members to migrate. These are irregular rainfall, temperature rise, deforestation, river erosion, landslide, drought/lowering of water level and flash floods. These hazards had profound impact on their ecosystem, resulting in the drying of mountain streams, shortage of water for irrigation and drinking, increased sedimentation and reduction in Jhum production. Over time many of the people left their villages in search of employment; many households now have one or more members working in other places (Siddiqui and Billah 2014). A case study in the Chitwan valley of Nepal reported that local mobility (within the Chitwan valley) was more likely to be influenced by environmental change rather than long-distance mobility (outside the Chitwan valley) (Massey et al. 2010). Another case study in the same area by Bohra-Mishra and Massey (2011) found a strong and consistent relationship between a local move (within Chitwan district) with neighbourhood density, increase in time required to collect fodder and firewood, and decline in agricultural productivity. This study also reported that environmental deterioration had little influence on migration outside Chitwan district (other districts in Nepal or overseas). However, an increase in time to collect firewood did increase the likelihood of male migration to other districts of Nepal or overseas (Bohra-Mishra and Massey 2011). A study by Mueller et al. (2014) found that heat stress increased long-term migration of men in rural Pakistan between 1991 and 2012. This migration was mainly driven by negative effects of heat stress on farm and non-farm income. A study by Banerjee et al. (2011) in four countries (China, India, Nepal, and Pakistan) across the HKH region reported that it was more likely that a household member would migrate in search of work in rural communities affected by rapid onset water hazards (e.g., riverine and flash floods) than those affected by slow onset water hazards (i.e., drought and water scarcity). A passing reference to the effects of environmental stressors on migration could be found in some studies (e.g., Ghobadi et al. 2005; Ministry of Agriculture and Forests 2013). For example, Ghobadi et al. (2005) reported that drought-affected households in Afghanistan are more likely to have members migrate for work than those households unaffected by drought. A report on migration in Bhutan suggested that factors such as predation by wildlife, drying up of water sources, outbreak of pests and diseases, and other calamities contributed to migration (Ministry of Agriculture and Forests 2013).

\subsection{Consequences of Labour Migration for Mountain Communities}

In this section, we analyse the ways in which migration outcomes have influenced the drivers of migration or intervening obstacles. In other words, we will be exploring how migration has acted as a driver of change. Lots of evidence on the consequences of labour migration are provided by country level studies. Findings from Afghanistan, Bhutan, and Nepal could be treated as mountain- or hill- specific experience. In the case of other countries, it is a challenge to infer $\mathrm{HKH}$ specific findings as only certain areas of these countries belong to the HKH region.

\subsubsection{Migration Reduces Mountain Poverty and Creates New Livelihood Opportunities}

The economic consequences of migration vary across countries and communities. A majority of the migrant-sending households, irrespective of whether they have an internal, cross-border, or international migrant workers, benefit economically from their investment in migration. Migration increases livelihood and employment opportunities, and more importantly, their financial income 
(Government of Nepal 2016; International Organization for Migration and Bangladesh Bank 2009; Mahmood 2011; Park and Wang 2010; Siddiqui and Mahmood 2015; Srivastava 2011; Zhao et al. 2012). About 59.1\% of rural population in Bhutan perceived remittances as the main benefit of having some of their household members living and working in urban areas (Ministry of Agriculture and Forests 2013). Using household panel data from China, Du et al. (2005) estimates that a household's income per capita increases by $8.5-13.1 \%$ if a member migrates for work, but the overall impact on poverty is modest because most poor people do not migrate. According to the Myanmar Labour Force Survey of $2015,85.1 \%$ of the international migrants remit money or goods with the average of USD 6,669 per annum. Urban households receive USD 33,330 from each international migrant family member. Rural households only receive the average of USD 1,661. This creates significant income gaps even among international migrants (Ministry of Labour, Immigration and Population 2016), let alone the income gaps between internal migrant households and non-migrant households. Griffith's (2016) analysis of the dataset from the Rural Household Survey found that remittances are not consistently used for improvements in the socio-economic conditions-levels of investments in livelihoods are higher among households whose remittance income acts as a supplement, whereas remittances-dependent households had higher proportion of their remittances spent on food, education, and health but less on livelihood and savings. A study that compared results from the Nepal Living Standards Survey found that one-fifth of poverty reduction in Nepal that occurred between 1995 and 2004 from $42 \%$ below poverty line to $31 \%$ in $2003 / 2004$ - can be attributed to increased levels of work-related migration and remittances sent home (Lokshin et al. 2010). The same study also found that while the increase in migration abroad was the leading cause of this poverty reduction, internal migration also played an important role (Lokshin et al. 2010). The difference between the per capita remittances received by an individual in the poorest and richest consumption quintiles in Nepal is large (Government of Nepal 2011). In the Gojal region of Gilgit-Baltistan, migration contributed to the sectoral and spatial livelihood diversification, leading to economic upliftment of the people (Benz 2016). Black et al. (2006) suggests that migration can increase inequality, especially if there are restrictions on who can migrate, and to where, as this can lead to 'capture' of profitable migration routes by wealthier groups, and/or limitation of migration benefits for the poor.

Though remittances are spent on consumption, these may also contribute to investment in agriculture or business. A number of studies suggest that remittances play a crucial role in rural economic development worldwide (Hugo 2002). Remittances can provide flows of capital into small farms in the peripheral rural areas (Ratha 2003). Furthermore, these remittances are more dependable and less volatile than other flows from abroad such as direct investment or official development projects (Ratha et al. 2011). Siddiqui and Mahmood (2015) found that short-term international migrants from Bangladesh contributed more to agricultural development than internal migrants by using improved seeds, adequate fertilizer, regular irrigation and insecticides. One of the Chittagong Hill Tracts districts was part of the study. This group also made investment in irrigation pump, power tiller, tractor, paddy separators and portable rice processing machines.

Cost has direct impact on the outcome of migration. Those who pay high costs are likely to gain less economic benefits. As the cost of migration was low in the 1980s and 1990s, short-term contract migration produced positive economic and social results for the majority of migrant-sending households. Studies have shown that over the years the cost of migration has become exorbitantly high and it is near impossible to reap sustainable economic benefit from migration (Siddiqui 2017). Visa trading in destination countries, the existence of tiers of intermediaries in both the countries of origin and destination, lack of accountability of recruiting agencies, lack of efficient governance system, and lack of information on safe migration among potential migrants have contributed to the soaring cost of migration. Among migrants from the HKH region, Bangladeshi migrants bear the highest migration cost. According to a report by the Migrant Forum Asia (n.d.), Bangladeshi migrant workers pay USD 25005000 to go to Gulf countries while their Indian and Nepali counterparts pay USD 1000-3000.

In a study conducted by the Ministry of Agriculture and Forests (2013), about $49.2 \%$ of rural households in Bhutan reported farm labour shortage as a result of out-migration. An analysis of the National Labour Force Survey from 2010 to 2012 reveals a different scenario, suggesting that rural employment expanded by $3.6 \%$ annually. However, the expansion is due to increased employment of people over 45 years of age; it is also important to note that rural agricultural employment of age group 15-24 declined by $24.7 \%$ per annum. It is evident that the elderly and women are now engaged in agriculture. Given the composition of farm labour, they are not able to optimally utilize the resources. This has direct impact on agricultural production and poses a risk to the national goal of food security and food self-sufficiency. However, these studies on labour shortage make an assumption that factors such as age structure, culture, labour market, and social norms remain constant. In the context of Bangladesh, international migration did result in labour shortage in some of the high migration areas, particularly during sowing and harvesting seasons. Interestingly it did not affect the agricultural production because internal migrants from other regions filled the labour shortage. In reality, then, benefits of international migration got distributed among the internal 
migrants in the form employment opportunities (Siddiqui and Mahmood 2015).

In recent times, improved access to technology has significantly shaped migration outcomes. Siddiqui and Mahmood (2015) found that in Bangladesh, 98\% of migrant households own at least one mobile phone. In the past migrants had little control over the remittances they sent, as it was difficult for them to communicate with the recipients on a regular basis. Once the family members received the remittances, they could get away with not using the money according to the migrant's wishes. Now that migrants own mobile phones, they can monitor how the remittance they send is being used on a day-to-day basis. One-fourth of the migrants interviewed in the study by Siddiqui and Mahmood (2015) reported they directly oversee the investment of remittance. For instance, they proactively shape decisions related to the purchase of land and agricultural equipment, the number of day labourers to be employed, and the type of seeds to be bought.

Migrant workers also bring back knowledge and skills from destination to origin communities. There is a lack of literature on social remittances and the contribution of returnees in the HKH region. For the international labour migrants, return is an integral part of their migration cycle. However only a small number of migrants plan their post return activities in advance (Wickramasekara 2011). A study on the contribution of returnees found that a large number of returnee migrants want to re-migrate as they feel that upon return they no longer have the contact with networks that would help them to establish a business or find jobs (Siddiqui and Abrar 2002). More recent studies, however, have found that many of the returnees have contributed in developing enterprises in rural areas (Siddiqui 2017).

\subsubsection{Increased School Enrolment, Better Outcomes for Children}

Ratha et al. (2011) highlighted that international migration contributes to the formation of human capital. Various studies showed that a disproportionately higher portion of remittances from international migration is spent on education and health than on everyday consumption (Adams and Page 2005; Adams et al. 2008; Nagarajan 2009; Ratha et al. 2011). Evidence from Nepal and Pakistan suggest that short-term international migration is associated with increased school enrolment (Bhadra 2007; Mansuri 2006). In China, some studies have examined the impact of parental migration on the development outcomes of children. For example, from a comprehensive dataset covering 141,000 children in ten provinces (from 27 surveys conducted between 2009 and 2013), Zhou et al. (2015) analysed nine indicators of health, nutrition, and education. They found that for all nine indicators, children left behind by their migrant parents with a caregiver (typically paternal grandparents - in their home communities) performed as well as or better than children living with both parents in their home communities. Similar studies are hardly available for most parts of the HKH region. Migration of a family member provides income to the elderly but also creates a vacuum for care (Hoang 2011). Age selective nature of migration means that elderly and children would be left behind and this may increase the workload. Evidence on these issues in the HKH region is sparse.

\subsubsection{Left Behind or Left in Charge}

Consequences of migration also depend on personal and household characteristics such as age, ethnicity, marital status, religion, sex, and wealth. Siddiqui and Abrar (2003) found that whether remittance will be used as current income or a portion of it will be invested in enterprises for further income generation depends on household members' age. Families with male members in the age group 25 to 45 years invested in different business enterprises, whereas most families with female members who had to be married-off spent more on dowry. Families who only had elderly members did not invest in business enterprises. Along with day-to-day consumption they invested a portion of the remittances in buying land. Siddiqui and Mahmood (2015) reported that male migrants invested more in agricultural development compared to female migrants. High-income households have more choices with respect to migration destination. Those who migrate to developed western countries belong to the richest economic quartile or to the highly skilled category. A majority of those who migrate to the Gulf region, other Arab countries and Southeast Asia to do unskilled work are not from high or middle-income households but they are mostly from households just above the poverty level. Poorer people are likely to opt for rural-to-rural and rural-to-urban, seasonal and temporary internal migration with lower salaries and wages and thus low remittances.

Beyond economic returns, recent studies also indicate that migration has yielded significant social benefits. For example, in the case of Nepalese Dalits, urban migration has not only provided them social, economic and educational opportunities, but also the possibility of escaping traditional caste-based discrimination (Pariyar and Lovett 2016). Siddiqui (2001) showed that majority of divorced and separated women became both economically and socially empowered 
through migration. Some found new partners and some others came out of abusive marriage. On the other hand, some of the stable marriages broke down because in the absence of their wives, migrants enter into new relationships. Similarly religious background also influences migration outcome. In Bangladesh, compared to the dominant religious group, minority communities have less access to international short-term contract migration (Siddiqui and Abrar 2003).

\subsubsection{Diaspora}

The general understanding is that migrants often contribute to the welfare of their communities of origin. The Afghan diaspora in the Netherlands helped in designing education curricula, translation of text books and training and skill development of manpower in Afghanistan (United Nations University 2017). The Nepal Institute of Development Studies and the World Bank (2009) survey reveals that collective remittances from both the Nepali diaspora and short-term migrants have contributed to the establishment of public libraries, trade schools, health posts in schools, water supply in remote areas, tower clocks in village centres, and computers in schools in Nepal. Migrants from India and Bangladesh have established orphanages and faith-based schools, mostly in their own villages (Siddiqui 2004; Singhvi 2001).

\subsubsection{Disaster Preparedness Is Not a Top Priority}

Recent studies that explore the role of migration in the context of vulnerability to environmental change in the $\mathrm{HKH}$ region of China (Banerjee et al. 2018; Yahui and Banerjee 2017), India (Banerjee et al. 2017), Nepal (Chapagain and Gentle 2015; Jaquet et al. 2016), and Pakistan (Gioli et al. 2014) suggest that households receiving remittances prioritise immediate consumption and economic needs initially, and then health and education. Remittances are used to respond to extreme events, providing finance for relief and reconstruction in the face of extreme events (e.g., earthquakes, floods). For example, remittances to Nepal increased in the aftermath of the 2015 earthquake, growing by $27.6 \%$ within three months from April to June 2015 compared to the same period the year before (The World Bank 2016c). Remittances are used to procure food and other basic needs during or in the aftermath of a disaster and rebuild livelihoods and lost assets (Banerjee et al. 2011; Suleri and Savage 2006). An increase in remittances in the aftermath of an extreme event is often temporary. In Nepal, inflow of remittances had slowed down, registering a single digit growth by January 2016. In three months from February to April 2016, remittances had contracted by 5.3\% (in USD terms) compared to the same period of the previous year (The World Bank 2016c).

The extent to which remittances would have a positive or negative role in remittance-recipient households and origin communities is context specific (Barnett and Webber 2009; De Haas 2012). Banerjee et al. (2018) found that remittance-recipient households in Baoshan County, Yunnan province, China have less adaptive capacity in response to drought than non-recipient households. The authors also reported that the adaptive capacity of those households who had received remittances over longer periods were found to have improved, and their exposure to such events was also lower (Banerjee et al. 2018). A case study in Assam state of India found that the duration for which remittances are received by a household has significant and positive association with the structural changes made in the house to address flood impacts (Banerjee et al. 2017). Chapagain and Gentle (2015) reported that remittances had been used by families in landslide prone communities in Jumla and Syangja districts of Nepal to buy land or house in a safe area, which permitted these families to leave environmentally fragile area and even find off-farm opportunities. Investment in climate change adaptation measures at the household level is often not made until later. Based on a study in three districts of Bangladesh, Siddiqui et al. (2018) found that a higher percentage of migrant households perceived that their economic status had improved over the preceding five years in comparison to non-migrant households. This along with other findings, led the researchers to conclude that those households that incorporate migration of a member with other in-situ practices adapt better to climate change stresses.

Out-migration has non-economic consequences in origin communities located in environmentally fragile areas. A study in Kaski district of western Nepal found that migration from uphill to downhill communities had resulted in land abandonment and an increase in forest cover in the upper part of the Harpan watershed (Jaquet et al. 2016). However, this process had also increased pressure on the land and exposure to flooding in the lower part of this watershed (Jaquet et al. 2016). There has been little research on migration, environment and climate change in mountain regions of Asia from gender perspective. Based on a study in West Karakoram region of Pakistan, Gioli et al. (2014) reports that there was an increase in female school enrollment due to remittances. However, male out-migration did not result in significant long-term changes in the intra-household and community-level decision-making 
power of women; women were not entitled to manage a household's economic assets (including remittances), and male out-migration limited the mobility of women left-behind.

\subsubsection{New Types of Politics}

Migration has contributed to increased political demands, including voting rights for migrants from the HKH countries. Since 2008 Bhutan has permitted its overseas citizens to vote and Afghanistan has allowed it since 2004 (The Record Nepal 2017). Changes in electoral laws had been approved by the Government of India that will permit Non-Resident Indians to cast their vote in state assembly and national parliamentary elections from overseas (The Indian Express 2017). The Election Commission of India had launched a web portal to register Non-Resident Indians, who would be able to cast their votes in their registered constituencies through a proxy. ${ }^{12}$ However, the inter-state migrants in India would still have to visit their registered constituencies to cast their vote (Bhatnagar 2017). At a public hearing, the National Election Commission of Bangladesh stated that it would explore a mechanism for allowing absentee voting for those citizens who are residing outside the country for work during the elections (The Daily Observer 2017). The Government of Nepal was ordered by the Supreme Court to draft a law that enables Nepali migrants abroad to vote (The Kathmandu Post 2018).

On important national matters, the diaspora sometimes plays an important role in their countries of destination. The Singhvi report (2001) highlights the role of Non-Resident Indians in the aftermath of Pokhran nuclear tests and during the Kargil conflict. This high-profile government report acknowledged that the Indian diaspora extended a valuable service to the Indian government by explaining its position to the policy makers as well as the public of their countries of destination, particularly in the United States of America.

In some HKH countries, irregular cross-border movement of people has become a major source of political tension. Migration between India and Bangladesh is a good example. Different actors operating at federal and state levels in India have securitized migration from Bangladesh to India by portraying migrants as a 'threat to national security', 'infiltrators from the east', 'terrorists', 'weapon traffickers', 'demographic invaders', and 'criminals'. This securitization and criminalization have resulted in border fencing and push back of less skilled Bangladeshi men and women (Siddiqui 2006).

\footnotetext{
${ }^{12}$ http://eci.nic.in/OverseasVoters/home.html.
}

\subsection{The Governance of Labour Migration in the HKH Region}

\subsubsection{National Policies, Laws and Acts}

In order to govern international labour migration, most of the HKH countries have framed different policies, enacted laws and established institutions. However, except China and to some extent India, none of these countries have such instruments or policies concerning internal migration.

In 2006 Bangladesh framed its first national policy on overseas employment. A major objective of these policies is to expand short-term contract labour migration (Wickramasekara 2011). The title of Pakistan's migration policy explains this point adequately-"National Emigration Policy: Promoting Regular Emigration and Protecting Emigrants." Nepal had enacted the Foreign Employment Act 2007 with the same objective. Along with promotion of labour migration, protection of the workers is also an important part of these policies. Under the Decent Work project of International Labour Organization, in 2016 the second overseas employment policy of Bangladesh had been drafted.

Afghanistan, Bangladesh, India and Nepal also have specific policies on female migration. Most of these countries initially either imposed a restriction or ban on migration of low skilled women. Over the years, due to demand in certain sectors of the labour market, which requires participation of women, most of these countries withdrew the bans or loosened the restrictions on female migration. For example, in 1997, Bangladesh placed a complete ban on all female migration for work. That same year it withdrew the ban on professionals but imposed restrictions on migration of unskilled female workers. But by 2003 it more or less withdrew the restrictions on female migration (Siddiqui 2008). Starting in 1985, the Government of Nepal has introduced various types of bans and restrictions on women's migration, the latest being in August 2012 when a ban was placed on migration of women under 30 years to be employed in domestic work (Sijapati et al. 2015).

Since 2000, some HKH countries have established new ministries or line agencies to govern international labour migration (Wicramasekera 2011). Afghanistan governs international migration through the Ministry of Labour, Social Affairs, Martyrs and Disabled (MoLSAMD). In India, emigration for overseas employment is regulated by the Protectorate of Emigrants (POE) as per the provisions of Emigration Act 1983. The Ministry of External Affairs has been the nodal agency supervising and controlling the emigration regulation and governance. However, in 2004, a new Ministry of Overseas Indian Affairs was created to look after the problems of emigrants and diaspora. It was merged with 
Ministry of External Affairs in 2016. The office of the POE, however, continues to function as before. The Department of Foreign Employment (DoFE) of Nepal and the Bureau of Emigration and Overseas Employment (BEOE) in Pakistan regulate labour movements from respective countries. In Bangladesh, the Ministry of Labour (MoL) oversees international labour migration. In 2001, the Ministry of Expatriates' Welfare and Overseas Employment (MoEWOE) was created by the Bangladesh government.

Until the early 1980s emigration from HKH countries that were part of the British Empire was governed by the 1922 Emigration Act of British India. After the oil price hike in the Middle East, when the number of migrants grew dramatically, governments of many countries in the $\mathrm{HKH}$ region enacted new laws. The main objectives of these laws were to facilitate the outflow of workers through regulation of recruitment agencies and protection of unskilled workers (Abrar 2005). Since 2000 a new set of laws emerged. For example, Nepal framed the Foreign Employment Act, 2007 replacing the Foreign Employment Act of 1985. The Emigration Ordinance (1979) and the Emigration Rules (1979) constitute the legal framework to safeguard the rights of Pakistani Migrant workers and regulate the activities of overseas employment promoters and recruiting agencies (Pakistan Institute of Legislative Development And Transparency 2008). Afghanistan framed the Labour Code of Afghanistan: Regulation for Sending Afghan Workers Abroad by Directorate of Rights and Labour Law, 2005 (Government of Afghanistan 2005). India framed a new law titled the Emigration Act 1983, replacing the Act of $1922 .^{13}$ In 2013, Bangladesh replaced its Emigration Ordinance 1982 (Number 29 of 1982) with the Migration and Overseas Employment Act 2013. The influence of the 1990 UN Convention is visible in the newly framed documents. Rights and welfare of migrants are more pronounced. Moreover, offences are also redefined and new types of crimes and fraudulences have been included. Punishments for committing those crimes have also been increased. The preamble to the 2013 Migration and Overseas Employment Act of Bangladesh clearly states that the new law is framed to make national law consistent with the 1990 Convention and other International Labour Organization Conventions.

The origin countries of the HKH region acknowledge the contribution of the diaspora in home country development. For example, India has undertaken a comprehensive policy to engage the diaspora in its development process. Some of these include: establishment of the then Ministry of Overseas Indian Affairs in 2004 to coordinate activities aimed at

\footnotetext{
${ }^{13}$ https://indiankanoon.org/doc/99408546/.
}

reaching out to the Indian diaspora and to build and foster networks with overseas Indians. Establishment of the Overseas Indian Facilitation Centre (OIFC), a not-for-profit public-private initiative of the Ministry of Overseas Indian Affairs, and the Confederation of Indian Industry (CII), is important in this respect. Currently, Overseas Indian Facilitation Centre's activities include responding to queries on various issues raised by the Indian diaspora, management of online business networking portal, and market forums in India and overseas. ${ }^{14}$ Since 2003, the Government of India has been hosting an annual diaspora conference, the Pravasi Bharatiya Divas. The event is designed to serve as a platform for interaction between overseas Indians, the Indian government, and interested segments of the Indian society, such as businesspersons and cultural and charity organizations. ${ }^{15}$

Policy provisions vary significantly in the Hindu Kush region with regard to internal migration. For instance, the Constitution of India provides for "freedom of movement" as well as "freedom of employment" anywhere in India (Government of India 1950). Additionally, there is also a specific law, the Inter State Migrant Workmen (Regulation of Employment and Conditions of Service) Act of 1979 (Government of India 1979) and Central Rules of 1980 (Government of India 1980) that is meant to guide internal labour migrants. The Inter-state Migrant Workmen Regulation Act 1979, deals with contractor-led movements of inter-state migrant labour. This law provides protection to internal migrants. But many workers do not move with contractors. They find work independently through the network of family, friends and kin and so do not fall under the purview of the Inter-state Migrant Workmen Regulation Act. Further, many schemes and programmes for workers in the informal sector are also applicable to migrant workers. But most of the time internal migrants cannot avail of those as they require registration and in some cases, identity cards which they often do not possess.

The right to work is a fundamental civil right in China. There are a number of laws and regulations applicable to the migrant workforce, such as the Labour Law of the People's Republic of China, which became effective in 1995, Law of the People's Republic of China on Employment Contracts, which became effective in 2008 (Standing Committee of the National People's Congress 1994, 2007) and Regulations on Work-Related Injury Insurances, which became effective in 2011 (State Council 2010). Moreover, the Interim Regulations on Residence Permits adopted by the State Council in 2015 contain a set of specific regulations that provide

\footnotetext{
14،Overseas Indian Facilitation Centre (OIFC)', http://moia.gov.in/ services. $\operatorname{asp} x$ ? ID $1=205 \& \mathrm{id}=\mathrm{m} 2 \& \mathrm{idp}=205 \&$ mainid $=196$ (accessed 3 August 2014).

${ }^{15}$ 'Pravasi Bharatiya Divas', http://www.pbd-india.com/about.html (accessed 6 August 2014).
} 
migrant workers access to basic public services and facilities in the destination city. Due to the household registration (hukou) system, however, citizens' freedom of movement within China is somewhat restricted. For example, migrants and their families have limited access to urban public services (e.g. healthcare, social security and education) if they do not have an urban hukou (Lai et al. 2014).

There is no policy on internal migration in Bangladesh. Although there is no restriction on any type of internal migration, urban development strategies, environmental policies such as the National Adaptation Programme of Action 2006 (NAPA), initial drafts of Bangladesh Climate Change Strategy and Action Plan 2009 (BCCSAP) or Disaster Risk Reduction Strategy perceive rural to urban migration as a problem of urbanization. Accordingly, most of these plans aim to reduce rural to urban migration through local level adaptation to climate change. While there are no explicit policies regulating internal migration in Pakistan, Gazdar (2003) makes an interesting case connecting urban planning and regulation with internal migration. Gazdar (2003) shows that the city managers follow 'settle first, regularize later' policy in Pakistan. When workers migrate to urban centres, they require access to housing and public goods, the provisioning of which is the hallmark of good urban planning.

\subsubsection{International Instruments}

With respect to international migration there are quite a few multilateral as well as bilateral instruments through which migration is governed. Most important of International Labour Organization instruments relating to migrant workers are the Migration of Employment Convention (Revised) 1949 (No: 97); the Migrant Workers' (Supplementary Provisions) Convention, 1975 (No. 143); and the Migrant Workers' Recommendation (No 151). The 1990 UN International Convention on the Protection of the Rights of all Migrant Workers and the Members of their Families (ICRMW) is the most comprehensive instrument relating to migrant workers. Multilateralism is important for protection of the rights of the migrant workers; unfortunately none of the countries of origin of the HKH region, except Bangladesh, have ratified the 1990 Convention, and nor has any destination country. Therefore, due to lack of ratification the rights assigned under the international instrument cannot be exercised.

Of late, major origin countries of the region such as Afghanistan, Bangladesh, China, India, Nepal, and Pakistan have joined regional consultative forums such as the Colombo Process and Abu Dhabi Dialogue. Further, most countries in the region have ratified the Convention on All Forms of Discrimination on Women (CEDAW), which includes specific provisions on women migrant workers, especially as part of General Recommendation No. 26. ${ }^{16}$ All the HKH countries espoused Sustainable Development Goals (SDGs) in pursuing their development agenda. It has major ramifications for both internal and international migrants of these countries. Target 8.8 of Goal 8 specifically mentions the migrants when it says, "Protect labour rights and promote safe and secure working environments for all workers, including migrant workers, in particular women migrants, and those in precarious employment."

In the absence of enforcement of multilateral instruments, bilateral agreement or memorandum of understanding are the only avenues under which labour migration is facilitated. Bilateral instruments focus on mutual intent to enhance employment opportunities in the destination countries; measures that destination countries will take for the protection and welfare of workers in the organized sector; regulation of the recruitment process in both countries; and establishment of a joint working group to ensure the implementation of the memorandum of understanding and bilaterally resolve any labour concerns. Barring a few, most of these bilateral instruments again focus on managing the recruitment and employment processes, with few, if any, provisions for protecting the workers or ensuring decent work for the migrants during their sojourn abroad (Siddiqui 2006; Wicramasekera 2015). Unfortunately destination countries are not keen on even signing bilateral agreements with such minimum rights. That is why the number of bilateral agreements is also low.

Labour migration in the region is characterized not only by short-term contract international migration but also by cross-border migration. For historical reasons, cross-border migration remains a sensitive issue. The Nepal-India Peace and Friendship Treaty 1950 and the open border between Nepal and India are perhaps exceptions. There are some regulations on cross-border movements. They mostly focus on regulating irregular movements, including cross-border trafficking. The Bangladesh-India Agreement for Mutual Legal Assistance on Criminal Issues and Transfer of Sentenced Persons of 2010 and the Bangladesh-India Agreement for Combating Terrorism, Transnational Organized Crimes, and Illegal Drug Trafficking of 2010 are examples of this regulation.

\subsubsection{Innovation in Governance and Migration}

Countries of the $\mathrm{HKH}$ region have innovated new methods in providing services to the migrants. Generating funds

${ }^{16}$ CEDAW (2009), /C/2009/WP.1/R General Recommendation no. 26 on Women Migrant Workers. 
outside government revenue and development budgets is one of them. As early as 1990, Bangladesh had innovated a method of generating fund to support migrant workers: Wage Earners' Welfare Fund. This fund is generated through subscription by migrant workers, consular fee charged in the embassies and interests charged from the bond money kept from the recruiting agency as license fee. The government has created a huge fund through this initiative. The line ministry uses this fund in providing welfare services to the migrants. The services include pre-departure training and briefing, 21-day training of female migrants, repatriation of deceased bodies, compensation to the injured and families of deceased, and managing shelter homes in destination (RMMRU 2016). Different countries are now replicating this model. Under the Foreign Employment Act of 2007, Nepal established the Foreign Employment Welfare Fund, which is a public fund managed by the Foreign Employment Promotion Board, in 2008 (Article 32 and Article 33, FEA 2007). ${ }^{17}$ Each out-bound worker pays a fee of NPR 1000 (approximately USD 9.6) to the welfare fund. This welfare fund also receives license fees from recruitment agencies and other institutions associated with foreign employment and grants provided by local or foreign institutions. To date, the welfare fund has primarily been used for repatriating seriously injured workers, repatriating mortal remains of deceased workers, providing compensation to the injured workers or families of deceased workers (Paoletti et al. 2014). However, despite the provisions in the law, initiatives from the Foreign Employment Promotion Board to provide skill-oriented training to migrant workers, reintegration programmes for returnees are limited alongside the low awareness about the welfare fund among migrant workers (Office of the United Nations High Commissioner for Human Rights 2018; Paoletti et al. 2014).

India has also established a fund to support the migrants. However, it does not charge the workers, rather it takes a security deposit of USD 2500 per worker from the foreign employer who hires an Indian worker. ${ }^{18}$ India also has an insurance scheme titled, the Pravasi Bharatiya Bima Yojana, which was launched in 2003 and amended in 2006, 2008 and 2017 (Government of India 2006). It is compulsory for all migrant workers who have obtained a clearance from the POE. Under this scheme, the migrant workers are insured for a minimum coverage of INR 0.3 million for the entire period of the employment contract. Some of the salient features of the scheme include: (i) cost of transporting the dead body, in

\footnotetext{
${ }^{17}$ Government of Nepal. 'Foreign Employment Act, 2007' Available at http://dofe.gov.np/new/uploads/article/foreign-employment-act_ 20120420110111.pdf.

${ }^{18} \mathrm{http}: / /$ mea.gov.in/rajya-sabha.htm?dt1/27853/QUESTION+NO3226 +INDIAN+MIGRANT+DOMESTIC+WORKERS+IN+GULF +COUNTRIES.
}

case of any such eventuality; (ii) transportation costs for workers who are stranded or experience substantive changes in the employment contract; (iii) travel support to migrant workers who fall sick or are declared medically unfit to work; and (iv) medical coverage of a minimum of INR 50,000 . India has also innovated a method of generating welfare fund for internal migrants who work in the construction sector. Under the Building and Other Construction Workers Act, 1996 it has created a provision for levying a tax for construction. Substantial funds have been collected by the Construction Welfare Boards in many states, but implementation of the programme is poor due to the lack of registration of workers (Bhagat 2014).

The Nepal government has undertaken a policy not to allow a worker to migrate through purchase of a work visa. The government is trying to set a basic condition for a job contract whereby the employer is responsible for bearing the cost of the visa, ticket, and all other related expenses of the worker. The recruitment agencies (hereafter RAs) are permitted to charge a maximum of NPR 10,000 (approximately USD 96) as a service and promotional fee only when the employing company overseas provides in writing that they will not bear the travel and recruitment costs of the concerned worker(s). Accordingly, the 'free-visa, free-ticket' or the 'zero-cost migration', as the scheme has come to be known, requires the prospective migrant to pay only for services such as pre-departure orientation training, medical check-ups, the government-mandated workers' welfare fund, and insurance. The policy is applicable to seven countries, namely Bahrain, Kuwait, Oman, Qatar, Saudi Arabia, the United Arab Emirates, and Malaysia. So far there are indications that while the policy measure is significant in principle, implementation has been weak, leading, in some instances, to more abuse of the workers (Amnesty International 2017; Sijapati et al. 2017). However, if Nepal does succeed, it will be a great innovation in workers' recruitment.

\subsubsection{Challenges of Migration Governance}

HKH countries face some major challenges in governing both internal and international migration. In the case of international migration, some common challenges that these countries face include high cost of migration, informality of the recruitment process, visa trading and lack of protection from abusive labour conditions. Some of the challenges are specific to women migrants, particularly for those who go abroad as domestic workers. Over the last ten years the governments of this region have been trying to reduce the cost of migration through bilateral agreements. In recent years, the origin country governments have placed the issue of cost of migration in multilateral fora such as Colombo Process, Abu Dhabi Dialogue and annual meetings of the UN Global Forum on 
Migration and Development. Some of these governments have tried to reduce the cost of migration by fixing the upper limit. However, none of these measures have produced their desired results yet. Although the governments have framed formal laws and created institutions to regulate short-term contract international migration most of the tasks of recruitment are done informally by the sub-agents. Most governments have attempted to abolish the system of sub-agents, but little headway has been made in this regard. Visa trading is another challenge. In some labour receiving countries, work visas change hands at least two to three times before they are made available to the recruiting agencies of origin countries through bidding. This issue is also being discussed in various fora. Governments of some destination countries have begun taking punitive measures against visa traders. Still the practice is pervasive. Restriction over movement, long working hours and in some cases physical and sexual abuse are some of the major challenges to overcome for the governments of origin and destination countries.

The lack of policy on internal migration in most HKH countries keep internal migrants outside the purview of government programmes and entitlements. In countries such as India, which has taken some policy measures to protect internal migrants, a negative attitude and hostility towards internal migrants persists, sustained by the 'sons of the soil' ideology despite the fact that the Indian Constitution guarantees the right to move as a fundamental principle under Article 19 (Weiner 1978). A group of internal migrants who are illiterate, low skilled, temporary and seasonal migrants are more vulnerable to various kinds of exclusion and denial of their rights in urban areas. These categories of migrants are excluded from social security programmes such as public distribution of food, access to education and healthcare and, most importantly, entitlement to housing at the destination because they lack proof of identity and residency. Social security programmes are place-bound and the implementation of such programmes fall under the purview of the state governments. Inter-state migrants face more hardships as social security programmes are not portable (Bhagat 2012). A major challenge for Afghanistan is to resettle the returnee refugees as well as the internally displaced persons ensuring their work opportunities and social protection.

\subsection{Conclusion}

This chapter has provided an outline of the patterns and trends of labour migration from the HKH region. It shows that migration trends are diverse. Internal migration is a feature across the region and the flow is towards major urban centres, as well as to areas of commercial agriculture. Some countries have a longer history of short-term international labour migration to the Gulf and other Southeast Asian countries and some others are recent joiners. There have been significant experiences of cross-border movements for work between India and Nepal, and India and Bangladesh, and from India to Bhutan.

Much migration in the region is gender specific. In the case of Afghanistan it is difficult to disentangle labour migration from refugee flows. Two-thirds of rural families of Bhutan have a member in an urban centre. Labour migration has grown mainly since the early 1990s in China and most migration here is intra-provincial. Long distance internal migration is an important characteristic of labour migration in India. International migration is almost non-existent from HKH region of Bangladesh. Myanmar has both internal and international migration and more than half the internal migrants are women.

The main driver of labour migration in the HKH region is 'search for a better life'. Limited opportunities in mountains reflect high dependence on agriculture, lack of market access and limited livelihood security. Economic growth of urban centres within and beyond the HKH region exerts a strong influence on migration. There is a strong demand for male workers from the mountain but also a growing demand for female workers in the domestic care and hospitality industries. Access to education and social networks are strong drivers of migration. Migration is highly age selective. Environmental degradation and climate stressors can weaken agricultural productivity or heighten risks contributing to labour migration, especially over shorter distance.

Country evidence shows that migration reduces mountain poverty. A significant portion of rural households benefit from migrant remittances. Remittances are spent on consumption, but may also contribute to investment in agriculture and other businesses. Despite fears of negative impacts on left behind children, migration helped increase school enrollment. Migration has contributed to increased political demands including voting rights.

An assessment of governance of labour migration in the HKH region shows that countries with significant international labour migration have developed comprehensive policies and regulations to govern international migration, often with dedicated ministries. However, policies on internal migration are yet to be framed except for a few countries. None of these countries, barring Bangladesh, have ratified the 1990 United Nations Convention on the Protection of the Rights of All Migrant Workers and the Members of their Families. Therefore, labour migration mostly takes place through bilateral agreements or memorandums of understanding. The SDGs specifically endorse policies to reduce the cost of migrant remittances and some HKH governments are actively pursuing these although there are many obstacles. Several countries in the region have specific institutions for the diaspora including overseas offices, welfare funds and diaspora focused financial instruments. 
HKH countries face many challenges in governing labour migration. Absence of a comprehensive policy on internal migration in some of the HKH countries keeps the internal migrants outside the purview of government programmes and entitlements. In some areas, polices are restrictive. Countries which have polices on internal migration do not always honour portability of rights. Whether countries have a regulated (India, China) or unregulated (Pakistan) approach to internal migration, there is a strong sedentary bias in policies that affect internal migrants, in contrast to international migration. In the case of international labour migration some common challenges that HKH countries face include high cost of migration, informality of the recruitment process, visa trading and lack of protection from abusive and forced labour conditions. Women who migrate as domestic workers face strict restrictions on movement, long working hours, and in some cases, physical and sexual abuse.

\subsection{Policy Recommendations and Way Forward}

On basis of the conclusions above, this section attempts to provide some recommendations. As all HKH countries have now reshaped their development goals in line with SDGs, the recommendations have been devised to correlate with relevant SDGs as well. Two SDGs apply directly to migration: Decent Work and Economic Growth (Goal: 8) and Reduce Inequality (Goal: 10). Several other SDGs have relevance for migration in terms of policy development.

\subsubsection{Regular, Safe and Orderly Migration}

SDG 8 talks about promoting inclusive and sustainable economic growth. Target 8.8 specifically underscores the need to protect the rights and promote safe working environments for migrant workers, including women migrants. Targets 8.5 (achieve full and productive employment and decent work) and 8.10 (access to banking, insurance and financial services for all) also have implications for migrants.

Target 10.7 specifically calls for facilitating orderly, safe, regular and responsible migration. We have attempted to demonstrate in this chapter that internal and international migrants are quite different and require different forms of support and interventions to ensure safety and stability. In respect to internal migrants, policies regarding urban planning, growth sector development, and climate change adaptation operational in rural and urban areas have to be targeted. Some of these countries impose barrier on internal, rural to urban migration. Relevant policies need to be reshaped on the basis of the demand of labour market.
Restrictive policies in destination countries remains the main hurdle for regular, safe and orderly migration. Destination countries need to frame more pragmatic policies that take into consideration the demand for different types of skills and services. We have argued that, along with bilateral negotiation, countries should encourage multilateralism to set common minimum standards for the migrant workers. The UN convention on Protection of Rights of All Migrant Workers and their Family Members (1990) and International Labour Organization instruments should be honoured in both origin and destination countries. The Kafala system in the Middle Eastern countries and the outsourcing system in some of the Southeast Asian countries need substantial reform. Origin countries also bear responsibility for insuring safe and orderly migration for their citizens. HKH countries are currently experimenting with different governance models in this regard and they can learn much from cross-country exchange among HKH neighbours and beyond.

\subsubsection{Protection of Migrants' Right and Social Security}

Target 8.8 of the SDGs highlights protecting labour rights and promoting a safe and secure working environment. The 1990 UN International Convention on the Protection of the Rights of All Migrant Workers and the Members of their Families (ICMW) is the most comprehensive instrument of its kind, and has only been ratified by one HKH country: Bangladesh.

This important agreement needs to be ratified by all HKH countries without any further delay. The UN needs to launch a global campaign to encourage ratification of the convention by the destination countries. The UN also needs to ensure that none of the rights of the migrants is compromised in the global compact for migration. HKH countries should advocate for more rigorous protection needs in the consultative forums of Colombo Process, Abu Dhabi Dialogue, and Bali Process. Most countries in the region have ratified the Convention on All Forms of Discrimination Against Women (CEDAW), which includes specific provisions for women migrant workers. During bilateral agreements, HKH countries can pursue protection of women migrants under the auspices of CEDAW.

The Rights of Internal Migrants are protected by the national laws of HKH countries. Decent work conditions entail the right to work, rights at work, social protections, and social dialogue. HKH countries need to provide protection from vulnerabilities and contingencies that take individuals out of work at old age, at times of sudden loss of livelihood, sickness, accident or death. In the case of informal work, these protections are almost non-existent. Attaining the SDG 8 would require establishing these rights. 


\subsubsection{Mainstreaming Migration into Development}

The section on the consequences of migration demonstrated the role of migration in reducing poverty, increasing living standards, and enhancing the social and economic development of migrants, their families, and their communities. To enhance the development impacts and to reduce negative consequences associated with migration, measures should be taken to optimize the potential gains. If low-income households are to fully benefit from migration this is an absolute necessity. For example, the effectiveness of Nepali policy on 'free-visa, free-ticket' for migrant workers should be evaluated, and, if it is successful, replicated in other $\mathrm{HKH}$ countries.

Almost all HKH countries have taken different steps to integrate international migration into their development policies. However, most of these policies look at international migrant workers and their remittances as of valuable tool for attaining national development goals. They rarely look for avenues that create space for migrants or their left-behind families to benefit from on-going national development interventions. For example, in the area of financial inclusion, migrants are seen as potential savers. Programmes need to be developed that would provide access to credit, training, business advisory services, and others incentives so that migrants or their families have the tools to turn themselves into investors (Goal 8 \& 9: Industry, Innovation and Infrastructure). Integrating return migrants in the development process is another strategy to use their accumulated skills and knowledge and, in many cases, their newly-acquired assets and wealth. Only China and India have specific policies in respect to internal migrants. In some cases, we have noted, these polices on internal migration work as barriers to integration rather than facilitators. Right-based and inclusive policies need to be framed targeting the internal migrants.

\subsubsection{Climate Change, Migrants and Urban Cities}

Each HKH country has developed its own policies, strategies, and action plans for climate change. These policies still regard internal migration as a threat. Policy planners need to transform their optics on labour migration and remittance into one of opportunity and as an added potential for adapting to climate change. This chapter suggests that the majority of migrants from communities affected by the climate change and variability move within their country of origin. Their major flows are from rural to urban centres, particularly to major urban centres. It was also observed that new migrant populations in urban centres face significant challenges associated with violence, social exclusion, discrimination in the labour market, human and physical insecurities, lack of access to health care, and exposure to new types of environmental risk. SDG 11 targets the creation of sustainable cities and community to enhance inclusive and sustainable urbanization. In order to attain SDG 11, HKH countries need to integrate housing, health, hygiene, sanitation, and security for migrants into their city planning efforts.

\subsubsection{Collection and Compilation of Migration Data}

Target 16.10 of SDG 16 deals with standardizing and public access to information and data. Migration data are highly deficient in HKH countries. In several HKH countries, labour force surveys provide data on emigration. But these are not available on a regular basis. On the other hand, some countries like India use the census to provide data on immigration rather than emigration. There is also a considerable delay in the publication of migration data by censuses compared to other population characteristics.

Sometimes migration data are provided on stock but not on flow and vice versa. There is a need for country-specific migration surveys at regular intervals in $\mathrm{HKH}$ countries. This information would help cross-country comparisons when trying to assess mountain economies. Furthermore, policy makers, researchers and NGOs could benefit from this data to fine tune and enhance their programmes and outreach on migration issues. However, in order to understand better the effects of migration in mountain areas, this data needs to have separate consideration for mountain areas in $\mathrm{HKH}$ countries. Data from other sources, such emigration at ports of departure, migrant registration prior to departure, insurance plans taken in connection with overseas employment, and remittances sent through banking channels would be useful to explore various dimensions of migration.

\section{References}

Abrar, C. R. (2005). Study on labour migration from SAARC countries: Reality and dynamics, A study commissioned by BATU-SAARC. Dhaka: Refugee and Migratory Movement Research Unit.

Adams, R. H., \& Page, J. (2005). Do international migration and remittances reduce poverty in developing countries? World Development, 33(10), 1645-1669.

Adams, R. H., Cuecuecha, A., \& Page, J. (2008). Remittances, consumption and investment in Ghana. World Bank Policy Research Working Paper, No. 4515. Washington D.C.: The World Bank.

Adhikari, K., Suwal, B., \& Sharma, M. (2008). Foreign labour migration and remittance in Nepal: Policy, institution and services. Washington D.C.: International Food Policy Research Institute. 
Ahmadi, B., \& Lakhani, S. (2017) The Afghan refugee crisis in 2016, Peace Brief, US Institute of Peace, Feb, 2017. Retrieved May 12, 2017, from https://www.usip.org/publications/2017/02/afghanrefugee-crisis-2016.

Ahmed, V., Sugiyarto, G., \& Jha, S. (2010). Remittances and household welfare: A case study of Pakistan. ADB Economics Working Papers No. 194. Manila: Asian Development Bank. http:// hdl.handle.net/11540/1536.

Amjad, R., Irfan, M., \& Arif, G. M. (2015). An analysis of the remittances market in Pakistan. In: R. Amjad, \& S. Burki (Eds.), Pakistan: Moving the economy forward (pp. 280-310). Cambridge, United Kingdom: Cambridge University Press. https://doi.org/10. 1017/CBO9781316271711.012.

Amnesty International. (2017). Turning people into profits: Abusive recruitment, trafficking and forced labour of Nepali migrant workers. London: Amnesty International.

Andrus, J. R. (1948). Burmese economic life. Stanford, California, CA: Stanford University Press.

Banerjee, S., Black, R., Mishra, A., \& Kniveton, D. (2018). Assessing vulnerability of remittance-recipient and non-recipient households in rural communities affected by extreme weather events: Case studies from south-west China and north-east India. Population, Space and Place. https://doi.org/10.1002/psp.2157.

Banerjee, S., Kniveton, D., Black, R., Bisht, S., Das, P. J., \& Tuladhar, S. (2017). Does financial remittance build household level adaptive capacity? A case study of the flood affected households of Upper Assam in India. KNOMAD Working Paper 18. Washington D.C.: The World Bank.

Banerjee, S., Gerlitz, J. Y., \& Hoermann, B. (2011). Labour migration as a response strategy to water hazards in the Hindu Kush-Himalayas. Kathmandu: International Centre for Integrated Mountain Development.

Bangladesh Bank. (2017). Monthly data on Wage earner's remittance. www.bangladeshbank.org.

Bangladesh Bureau of Statistics. (2016). Bangladesh sample vital statistics. Dhaka, Bangladesh: BBS. https://www.google.com/url? $\mathrm{sa}=\mathrm{t} \& \mathrm{rct}=\mathrm{j} \& \mathrm{q}=\& \mathrm{esrc}=\mathrm{s} \&$ source $=$ web $\& \mathrm{~cd}=11 \& \mathrm{cad}=\mathrm{rja} \& u a c t=$ $8 \&$ ved $=$ OahUKEwiGgoDwkK7XAhVBqI8KHVV4DAYQFghDMAo\&url= http\%3A\%2F\%2F203.112.218.65\%3A8008\%

2FWebTestApplication\%2Fuserfiles\%2FImage\%2FLatestReports\% 2FSVRS_2015.pdf\&usg=AOvVaw2Z_Xp9SMVvFwIEgxVfIsDh.

Barnett, J. R., \& Webber, M. (2009). Accommodating migration to promote adaptation to climate change. The Commission on Climate Change and Development. Policy Research Working Paper 5270. Washington D.C.: The World Bank.

Benz, A. (2016). Framing modernization interventions: Reassesing the role of migration and translocality in sustainable mountain development in Gilgit-Balitstan, Pakistan. Mountain Research and Development, 36(2), 141-152.

Bhadra, C. (2013). Final report on impact offoreign labour migration to enhance economic security and address VAW among Nepali women migrant workers and responsiveness of local governance to ensure safe migration, submitted to MoWCSW, MoLE, MoFALD of GoN.

Bhadra, C. (2007). Women's international labour migration and impact of their remittance on poverty reduction: Case of Nepal. Seminar presentation on Labour Migration, Employment and Poverty Alleviation in South Asia, Kathmandu, 9-10 August.

Bhagat, R. B. (2014). Urban migration tends, challenges and opportunities in India. Background Paper to World Migration Report 2015. Geneva: International Organization for Migration.

Bhagat, R. (2012). A turnaround in India's urbanization. Asia-Pacific Population Journal, 27(2), 23-39.

Bhagat, R. B., Keshri, K., \& Ali, I. (2013). Emigration and flow of remittances. Migration and Development, 2(1), 93-105.
Bhandari, P. (2004). Relative deprivation and migration in an agricultural setting of Nepal. Population and Environment, 25(5), 475-499.

Bhatnagar, G. V. (2017, August 3). Modi government's decision to allow proxy voting by NRIs may kick up a hornet's nest. The Wire. https://thewire.in/diplomacy/centres-decision-allow-proxy-votingrights-nri-may-kick-hornets-nest.

Bjelica, J. (2016). Over half a million Afghans flee conflict in 2016: A look at the IDP statistics, rights and freedoms, Afghan Analysts Network, December 2016.

Black, R., Bennett, S. R. G., Thomas, S. M., \& Beddington, J. R. (2011). Climate change: migration as adaptation. Nature, 478, 447449. https://doi.org/10.1038/478477a.

Black, R., Natali, C., \& Skinner, J. (2006). Migration and inequality. Background Paper for World Development Report 2006. Washington DC: The World Bank.

Bohle, H. G., \& Adhikari, J. (1998). Rural livelihoods at risk: How Nepalese farmers cope with food insecurity. Mountain Research and Development, 18, 321-332.

Bohra-Mishra, P., \& Massey, D. S. (2011). Environmental degradation and out-migration: New evidence from Nepal. In E. Piguet, A. Pécoud, \& P. de Guchteneire (Eds.), Migration and climate change (pp. 74-101). Cambridge, CAMBS: Cambridge University Press.

Bruslé, T. (2008). Choosing a destination and work. Mountain Research and Development, 28(3), 240-247.

Bureau of Manpower, Employment and Training. (2017). Overseas employment in 2017. Dhaka, Bangladesh: BMET. http://www.bmet. org.bd/BMET/stattisticalDataAction.

Bureau of Manpower, Employment and Training. (2016). Overseas Employment in 2016. Dhaka, Bangladesh: BMET. http://www. bmet.org.bd/BMET/stattisticalDataAction.

Chapagain, B., \& Gentle, P. (2015). Withdrawing from Agrarian livelihoods: Environmental migration in Nepal. Journal of Mountain Science, 12(1), 1-13.

De Haas, H. (2012). The migration and development pendulum: A critical view on research and policy. International Migration, 50(3), $8-25$.

Department of Population. (2016). The 2014 Myanmar population and housing census: Thematic report on migration and urbanization. Nay Pyi Taw, Myanmar: DoP.

Department of Population. (2015). The 2014 Myanmar population and housing census: The union report. Nay Pyi Taw, Myanamar: DoP.

Du, Y., Park, A., \& Wang, S. (2005). Migration and rural poverty in China. Journal of Comparative Economics, 33(4), 688-709.

EC working to ensure voting rights of NRBs. (2017, September 24). The Daily Observer. http://www.observerbd.com/details.php?id= 96519.

Fu, Q., \& Ren, Q. (2010). Educational inequality under China's rural-urban divide: The Hukou system and return to education. Environment and Planning A, 42(3), 592-610.

Gazdar, H. (2003). A review of migration issues in Pakistan. Paper prepared and presented at the Regional Conference on Migration, Development and Pro-Poor Policy Choices in Asia. The Conference was jointly organised by the Refugee and Migratory Movements Research Unit, Bangladesh, and the Department for International Development, UK.

Ghobadi, N., Koettl, J., \& Vakis, R. (2005). Moving out of poverty: Migration insights from rural Afghanistan. Working Paper Series. Kabul: Afghanistan Research and Evaluation Unit (AREU).

Gioli, G., Khan, T., Bisht, S., \& Scheffran, J. (2014). Migration as an adaptation strategy and its gendered implications: A case study from the Upper Indus Basin. Mountain Research and Development, 34 (3), 255-265.

Gong, X., Kong, S. T., Li, S., \& Meng, X. (2008). Rural-urban migrants. China's dilemma (pp. 110-152). 
Government clears proxy vote move for NRIs. (2017, August 3). The Indian Express. http://indianexpress.com/article/india/governmentclears-proxy-vote-move-for-nris-4779759/.

Government of Afghanistan. (2005). Regulation for sending Afghan workers to abroad (unofficial English translation) in Official Gazette, no. 906, (Kabul, Ministry of Labour, Social Affairs, Martyrs and Disabled (MoLSAMD), Directorate of Rights and Labour Law).

Government of the Islamic Republic of Afghanistan (GIRoA). (2015). The state of Afghan Cities 2015, GIRoA Kabul, 2015.

Government of India. (2006). Pravasi Bharatiya Bima Yojana. New Delhi: Ministry of External Affairs. http://www.mea.gov.in/oe-faq. htm.

Government of India. (1980). Inter-state Migrant Workmen (Regulation of Employment and Conditions of Service Conditions) Central Rules. New Delhi: Ministry of Labour.

Government of India. (1979). The Inter-state Migrant Workmen (Regulation of Employment and Conditions of Service) Act of 1979. Office of Chief Labour Commissioner (Central). New Delhi: Ministry of Labour. http://clc.gov.in/clc/clcold/Acts/shtm/ismw.php. Government of India. (1950). The Constitution of India. New Delhi.

Government of Nepal. (2011). Nepal Living Standards Survey 2010/11, vol. 2. Kathmandu: Central Bureau of Statistics.

Government of Nepal. (2013). Nepal thematic report on food security. Kathmandu: National Planning Commission.

Government of Nepal. (2015). Guidelines related to managing domestic workers going for foreign employment, 2015.

Government of Nepal. (2016). Labour migration for employment. A status report for Nepal: 2014/2015. Kathmandu: Ministry of Labour and Employment.

Griffiths, M. (2016). Remittance economy in Rural Myanmar. In M. Griffiths \& M. Ito (Eds.), Migration from Myanmar: Perspectives from current research (pp. 99-116). Yangon, Myanmar: Social Policy and Poverty Research Group.

Hall, S (2013). Complexities and challenges in Afghan migration: Policy and research event, IS Academy Policy Brief | No. 14. Retrieved May 12, 2017, from http://samuelhall.org/REPORTS/ Complexities\%20and\%20Challenges\%20in\%20Afghan\% 20Migration.pdf.

Hoang, L. (2011). Impact of internal and international labour migration: South-East Asia. Migrating out of Poverty Research Programme Consortium Working Paper 28. Brighton: University of Sussex.

Hoermann, B., Banerjee, S., \& Kollmair, M. (2010). Labour migration for development in the western Hindu Kush-Himalayas. Kathmandu: International Centre for Integrated Mountain Development.

Hoermann, B., \& Kollmair, M. (2008). Labour migration and remittances in the Hindu Kush-Himalayan region. Kathmandu: International Centre for Integrated Mountain Development.

Hu, X., Cook, S., \& Salazar, M. A. (2008). Internal migration and health in China. The Lancet, 372(9651), 1717-1719.

Hugo, G. (2002). Effects of international migration on the family in Indonesia. Asian and Pacific Migration Journal, 11(1), 13-46.

Huo, W., Deng, G., Wang, P., \& Yang, X. (2006). The pull of inter-provincial migration of rural labor force and its influence on policy making. Ecological Economy, 2, 25-31.

Intergovernmental Panel on Climate Change (IPCC). (2014). Climate change 2014: Impacts, adaptation and vulnerability. Contribution of Working Group II to the Fifth Assessment Report of the Intergovernmental Panel on Climate Change. Cambridge university press.

International Labour Organization. (2015). No easy exit-Migration bans affecting women from Nepal. Labour Migration Branch (MIGRANT) - Geneva: ILO.
International Organization for Migration. (2014). Afghanistan Migration Profile, International Organisation for Migration, p. 22. Retrieved February 27, 2017, from http://samuelhall.org/wpcontent/uploads/2016/07/IOM-Afghanistan-Migration-Profile.pdf.

International Organization for Migration and Bangladesh Bank. (2009). Nationwide household remittance survey in Bangladesh. Dhaka: IOM.

Ito, M. (2016). Myanmar migrant workers in Thailand-Their characteristics, migration experiences and aspirations on return. In M. Griffiths \& M. Ito (Eds.), Migration in Myanmar: Perspectives from current research (pp. 88-98). Yangon, Myanmar: Social Policy and Poverty Research Group.

Jain, A. (2010). Labour migration and remittances in Uttarakhand. Kathmandu: International Centre for Integrated Mountain Development.

Jaquet, S., Shrestha, G., Kohler, T., \& Schwilch, G. (2016). The effects of migration on livelihoods, land management, and vulnerability to natural disasters in the Harpan watershed in Western Nepal. Mountain Research and Development, 36(4), 494-505.

Kollmair, M., \& Banerjee, S. (2011). Drivers of migration in mountainous regions of the developing world: A review. Report submitted to Foresight Environmental Migration Project. London: UK Government Office of Science (GO-Science).

Kreutzmann, H. (2004). Accessibility for high Asia: Comparative perspectives on Northern Pakistan's traffic infrastructure and linkages with its neighbors in the Hindukush-Karakoram-Himalaya. Journal of Mountain Science, 1(3), 193-201.

Kyaw, A. T. (2015, September 2). Informal cash flows threaten kyat policy. Myanmar Times. https://www.mmtimes.com/business/ 16267-informal-cash-flows-threaten-kyat-policy.html.

Lai, F., Liu, C., Luo, R., Zhang, L., Ma, X., Bai, Y., et al. (2014). The education of China's migrant children: The missing link in China's education system. International Journal of Educational Development, 37, 68-77.

Li, Q., Huang, J., Luo, R., \& Liu, C. (2013). China's labor transition and the future of China's rural wages and employment. China \& World Economy, 21(3), 4-24.

Liang, Z., \& Ma, Z. (2004). China's floating population: New evidence from the 2000 census. Population and Development Review, 30(3), 467-488.

Lokshin, M., Bontch-Osmolovski, M., \& Glinskaya, E. (2010). Work-related migration and poverty reduction in Nepal. Review of Development Economics, 14(2), 323-332.

Lusome, R., \& Bhagat, R. B. (2013). Migration and workforce participation in the Himalayan states. In: T. V. Sekher, A. Singh, \& S. Parsuraman (Ed.), Population, health and development (pp. 435446). Delhi, India: Academic Foundation.

Mahmood, R. (2011). Cross labour mobility, remittances and economic development in South Asia. Washington D.C., United States of America: The World Bank.

Mansuri, G. (2006). Migration, sex bias, and child growth in rural Pakistan. Policy Research Working Paper No. 3946. Washington D.C.: The World Bank.

Massey, D. S., Axinn, W. G., \& Ghimire, D. J. (2010). Environmental change and out-migration: Evidence from Nepal. Population and Environment, 32(2), 109-136.

Massey, D., Axinn, W., \& Ghimire, D. (2007). Environmental change and out-migration: Evidence from Nepal. Population Studies Center Research Report 07-615. Ann Arbor, MI: Population Studies Center. Migrant Forum Asia. (n.d). Open Working Group on Labour Migration and Recruitment, Recruitment Fees and Migrants' Rights Violation Policy Brief \#1, MFA, Manila.

Millions still waiting on a chance to vote. The Record (2017, May 11). The Record Nepal http://www.recordnepal.com/wire/news-analysis/ millions-still-waiting-on-a-chance-to-vote/. 
Ministry of Agriculture. (2006). Rural-urban migration in Bhutan. Bhutan: Thimphu.

Ministry of Agriculture and Forests. (2013). Migration in Bhutan (Its Extent, Causes and effects). Bhutan: Thimphu.

Ministry of Human Resources and Social Security. (2013). Annual statistical bulletin of human resources and social security development in 2013. Beijing, China: MHRSS [in Chinese]. Retrieved from http://www.mohrss.gov.cn/SYrlzyhshbzb/zwgk/szrs/ndtjsj/ tjgb/201405/t20140529_131147.htm .

Ministry of Labour and Human Resources. (2015). Labour force survey report. Bhutan: Thimphu.

Ministry of Labour, Immigration and Population. (2016). Report on Myanmar labour force survey: January-March 2015. Myanmar: Nay Pyi Taw.

Mohanty, S., \& Bhagat, R. B. (2013). Spatial pattern of urbanisation and urban growth in Western Himalayan region in India. In: T.V. Sekher, A. Singh, S. Parsuraman, (Eds.), Population, health and development (pp. 413-434). Delhi, India: Academic Foundation.

Mueller, V., Gray, C., \& Kosec, K. (2014). Heat stress increases long-term human migration in rural Pakistan. Nature Climate Change, 4, 182-185. https://doi.org/10.1038/nclimate2103.

Nagarajan, S. (2009). Migration, remittances, and household health: Evidence from South Africa (Unpublished doctoral thesis). United States of America: George Washington University.

National Bureaus of Statistics of China. (2017). The 2016 migrant worker monitoring survey report. Beijing, China: NBSC. Retrieved November 8, 2017, from http://www.stats.gov.cn/tjsj/zxfb/201704/ t20170428_1489334.html.

National Bureau of Statistics of China. (2016). China statistical yearbook 2016. Beining, China: NBSC.

National Sample Survey Organization. (2010). Migration in India 2007-08. New Delhi, India: NSSO.

Neetha, N. (2003). Migration, social networking, and employment: a study of domestic workers in Delhi. NLI Research Studies Service No. 2002/37. Noida, UP: VV Giri National Labour Institute.

Nepal Economic Forum. (2014). Docking Nepal's economic analysis. Lalitpur: Nefport.

Nepal Institute of Development Studies and World Bank. (2009). Nepal migration survey. Kathmandu: NIDS. (unpublished).

Nordland, R. (2016, November 4). Afghanistan itself is now taking in the most Afghan migrants. The New York Times. http://www.nytimes. com/2016/11/05/world/asia/afghanistan-migrants.html?_r=0.

Office of the United Nations High Commissioner for Human Rights. (2018). End-of-mission statement of the UN Special Rapporteur on the human rights of migrants on his visit to Nepal,' 5 February 2018. http://www.ohchr.org/en/NewsEvents/Pages/DisplayNews. aspx?NewsID=22632\&LangID=E.

Olimova, S., \& Olimov, M. (2007). Labor migration from mountainous areas in the Central Asian region: Good or evil? Mountain Research and Development, 27(2), 104-108.

Opel, A. (2005). Bound for the city: A study of rural to urban labour migration in Afghanistan. Working Paper Series. Kabul: Afghanistan Research and Evaluation Unit.

Pakistan Bureau of Statistics. (2011). The labor force survey. Islamabad, Pakistan: PBS.

Pakistan Institute of Legislative Development and Transparency. (2008). Overseas Pakistani workers: Significance and issues of migration. Briefing Paper No. 34. Islamabad: PILDAT.

Paoletti, Sarah, Taylor-Nicholson, Eleanor, Sijapati, Bandita, \& Farbenblum, Bassina. (2014). Migrant workers' access to justice at home: Nepal. New York: Open Society Foundations.

Park, A., \& Wang, D. (2010). Migration and urban poverty and inequality in China. China Economic Journal, 3(1), 49-67.

Pariyar, B., \& Lovett, J. C. (2016). Dalit identity in urban Pokhara. Nepal. Geoforum, 76, 134-147.
Ratha, D. (2003). Worker's remittances: The important and stable source of external development finance. Global Development Finance. Washington D.C.: The World Bank.

Ratha, D., Mohapatra, S., \& Scheja. E. (2011). Impact of migration on economic and social development: A review of evidence and emerging issues. Policy Research Working Paper No. 5558. Washington DC: The World Bank.

Refugee and Migratory Movements Research Unit. (2017). Labour migration from Bangladesh 2016: Achievements and challenges. Dhaka: RMMRU.

Refugee and Migratory Movements Research Unit. (2016). Institutional capacity building for management of the wage earners' welfare fund. Policy Brief 17, Dhaka: RMMRU. https://www.dropbox.com/ s/po9xaq6420tz14o/Policy\%20Brief\%2017.pdf?dl=0.

SC orders govt to ensure migrants' right to vote. (2018, March 23). The Kathmandu post. http://kathmandupost.ekantipur.com/news/201803-23/sc-orders-govt-to-ensure-migrants-right-to-vote.html.

Shrestha, S. S., \& Bhandari, P. (2007). Environmental security and labor migration in Nepal. Population and Environment, 29(1), 25-38.

Siddiqui, T. (Ed.). (2017). Untold stories of migrants: Dreams and realities. Dhaka, Bangladesh: Refugee and Migratory Movement Research Unit.

Siddiqui, T. (2008). Migration and gender in Asia. United Nations Economic and Social Commission for Asia and the Pacific Population Division, Department of Economic and Social Affairs Bangkok, Thailand. http://www.un.org/esa/population/meetings/ EGM_Ittmig_Asia/P06_Siddiqui.pdf.

Siddiqui, T. (2006). Securitization of irregular migration: The South Asian Case. In: R. Emmers, M. C. Anthony, \& A. Acharya (Ed.), Studying non traditional security in Asia (pp. 143-167). Singapore: Marshall Cavendish Academic.

Siddiqui, T. (2004). Institutional diaspora linkage: The emigrant Bangladeshis in UK and USA. Dhaka: GOB and IOM.

Siddiqui, T. (2001). Transcending boundaries: Labour migration of women from Bangladesh. Dhaka: University Press Limited.

Siddiqui, T., \& Abrar, C. R. (2003). Migrant workers' remittances and micro finance in Bangladesh. Geneva: International Labour Organization.

Siddiqui, T., \& Abrar, C. R. (2002). Contribution of returnees: An analytical survey of post return experiences. Dhaka: International Organization for Migration.

Siddiqui, T., \& Billah, M. (2014). The role of labour migration in climate change adaptation in Bangladesh with a special focus on the Chittagong Hill Tract region. Working Paper Series no. 47. Dhaka: RMMRU.

Siddiqui, T., Bhuiyan, M. R. A., Kniveton, D., Black, R., Islam, M. T., \& Martin, M. (2018). Situating migration in planned and autonomous practices in Bangladesh. In S. I. Rajan \& R. B. Bhagat (Eds.), Climate change, vulnerability and migration (pp. 119-146). Oxon, United Kingdom: Routledge.

Siddiqui, T., \& Mahmood, R. (2015). Impact of migration on poverty and local development in Bangladesh, SDC and RMMRU.

Sijapati, B., Ayub, M., \& Kharel, H. (2017). In: S. Irudaya Rajan (Ed)., Making migration free: An analysis of Nepal's 'free-visa, free-ticket'scheme. South asia migration report 2017: Recruitment, remittances and reintegration. Abingdon and London: Routledge.

Sijapati, B., Bhattarai, A., \& Pathak, D. (2015). Analysis of labour market and migration trends in Nepal. Kathmandu: Deutsche Gesellschaft für Internationale Zusammenarbeit and International Labour Organization.

Singhvi, L. M. (2001). The Indian diaspora. The Report of the High Level Committee on Indian Diaspora (HLCID), 19th December 2001.

Srivastava, R. (2012). Internal migration in India: An overview of its features, trends and policy challenges. In: UNESCO/UNICEF 
National Workshop on Internal Migration and Human Development in India, 6-7 December 2011, Workshop Compendium (Vol. 2). Workshop Papers. New Delhi, UNESCO/UNICEF.

Srivastava, R. (2011). Internal migration in India. Background Paper Prepared for the Migrating Out of Poverty Research Programme Consortium, University of Sussex.

Standing Committee of the National People's Congress. (2007). Law of the People's Republic of China on Employment Contracts. Retrieved November 8, 2017, from http://www.gov.cn/jrzg/200706/29/content_667720.htm. China.

Standing Committee of the National People's Congress. (1994). Labor Law of the People's Republic of China. Retrieved November 8, 2017, from http://www.gov.cn/banshi/2005-05/25/content_905.htm. China.

State Council. (2010). Regulations on work-related injury insurances. China. Retrieved November 8, 2017, from http://www.gov.cn/ gongbao/content/2011/content_1778064.htm. China.

Subedi, B. (1991). International migration in Nepal: Towards an analytical framework. Contribution to Nepalese Studies, 18(1), 83102.

Suleri, A., \& Savage, K. (2006). Remittances in crisis: A case study of Pakistan. Humanitarian policy group background paper. London: Overseas Development Institute.

The World Bank. (2016a). Migration and remittances: Recent developments and outlooks. Migration and Development brief No. 26. Washington D.C: World Bank.

The World Bank. (2016b). A country on the move: Domestic migration in two regions of Myanmar. Yangon: World Bank.

The World Bank. (2016c). Remittances at risk. Nepal Development Update. Kathmandu: World Bank. http://documents.worldbank.org/ curated/en/564551468198011442/pdf/106393-WP-PUBLIC-ADDSERIES-Nepal-Development-Update-2016.pdf.

The World Bank. (2014). Migration and development brief No. 23, 2014, Washington, D.C.

United Nations. (2015). The world population prospects: The 2015 revisions. UN: Population Division.

United Nations Department of Economic and Social Affairs. (2013a). Cross-national comparisons of internal migration: An update on global patterns and trends. Population Division Technical Paper 2013/1. New York, United Nations.

United Nations Department of Economic and Social Affairs. (2013b). International migration report 2013. New York: United Nations.
United Nations Department of Economic and Social Affairs. (2015). Trends in international migration stock: Migrants by destination and origin (United Nations database POP/PB?MIG?Stock/Rev 2015). http://www.un.org/en/development/desa/population/migration/data/ estimates2/estimates15.shtml.

United Nations University. (2017). Highly skilled Afghan diaspora contributes to innovation and change, United Nations University. http://unu.edu/publication.

United Nations High Commissioner for Refugees. (2017). Facts and figures about refugees. Retrieved February 27, 2017, from http:// www.unhcr.ie/about-unhcr/facts-and-figures-about-refugees.

Ura, K. (2013). Migration in Bhutan: To the west and towns, The Bhutanese.

Weiner, M. (1978). Sons of the soil: Migration and ethnic conflict in India. Princeton, NJ: Princeton University Press.

Wen, M., \& Lin, D. (2012). Child development in rural China: Children left behind by their migrant parents and children of nonmigrant families. Children Development, 83(1), 120-136.

Wickramasekara, P. (2015). Bilateral agreements and memoranda of understanding on migration of low skilled workers: A review. Report prepared for the Labour Migration Branch. Geneva: International Labour Organization.

Wickramasekara, P. (2011). Labour migration in South Asia: A review of issues, policies and practices. International Migration Paper No. 108. Geneva: International Labour Organization.

Yahui, Z., \& Banerjee, S. (2017). The role of out-migration in villagers' adaptation to drought $-\mathrm{A}$ case of Baoshan, Yunnan, China. Advances in Climate Change Research, 13(4), 398-404.

Zhang, L., Liu, C., Bai, Y., Dong, Y., \& Wang, W. (2017). Mid-term progress report submitted to the National Natural Science Foundation of China. The Center for Chinese Agricultural Policy. Beijing: Chinese Academy of Sciences.

Zhao, R., Liu, Y., \& Yan, Y. (2012). Labor migration choice and its impacts on households in rural China. The Agricultural and Applied Economics Association's 2012 AAEA Annual Meeting. Seattle: The Agricultural and Applied Economics Association.

Zhou, C., Sylvia, S., Zhang, L., Luo, R., Yi, H., Liu, C., et al. (2015). China's left-behind children: Impact of parental migration on health, nutrition, and educational outcomes. Health Affairs, 34(11), 1964-1971.
Open Access This chapter is licensed under the terms of the Creative Commons Attribution 4.0 International License (http:// creativecommons.org/licenses/by/4.0/), which permits use, sharing, adaptation, distribution and reproduction in any medium or format, as long as you give appropriate credit to the original author(s) and the source, provide a link to the Creative Commons license and indicate if changes were made.
The images or other third party material in this chapter are included in the chapter's Creative Commons license, unless indicated otherwise in a credit line to the material. If material is not included in the chapter's Creative Commons license and your intended use is not permitted by statutory regulation or exceeds the permitted use, you will need to obtain permission directly from the copyright holder. 